\title{
Alpha Calcium/Calmodulin-Dependent Protein Kinase II Selectively Expressed in a Subpopulation of Excitatory Neurons in Monkey Sensory-Motor Cortex: Comparison with GAD-67 Expression
}

\author{
E. G. Jones, G. W. Huntley, ${ }^{\mathrm{a}}$ and D. L. Benson ${ }^{\mathrm{b}}$ \\ Department of Anatomy and Neurobiology, University of California at Irvine, Irvine, California 92717
}

In situ hybridization histochemistry and immunocytochemistry, including double immunofluorescence, were used to study the populations of neurons expressing the $\alpha$ subunit of type II calcium/calmodulin-dependent protein kinase (CAM II kinase- $\alpha$ ) or glutamic acid decarboxylase (GAD) in the somatic sensory and motor areas of the macaque monkey cerebral cortex. Sections were subjected to in situ hybridization using radioactive, complementary RNA probes specific for monkey CAM II kinase- $\alpha$ or 67 kDa GAD mRNAs. Others were stained immunocytochemically for CAM II kinase $-\alpha$ and/or GABA.

CAM II kinase- $\alpha$ and GAD-67 are expressed in different populations of cells, with no colocalization. CAM II kinase$\alpha$ is expressed in pyramidal cells of layers II-VI, especially layers II and III, as well as in certain small nonpyramidal cells of layer IV in areas 3a, 3b, 1, and 2 and of middle regions of area 4 . Both cell types produce excitatory amino acid transmitters. Therefore, as in subcortical regions, CAM II kinase- $\alpha$ will be found on the presynaptic side of excitatory synapses but on the postsynaptic side only when these synapses occur on excitatory neurons in the sensory-motor cortex.

Quantitative examination showed that CAM II kinase- $\alpha$ immunoreactive cells form, on average, approximately $50 \%$ of the total neuronal population in each area, while GABA immunoreactive or GAD cRNA hybridized cells form approximately $25-30 \%$. Thus, CAM II kinase- $\alpha$ expressing cells cannot account for the total population of non-GABAergic cortical cells, and a certain proportion of the pyramidal cells probably do not express it.

In other cortical areas, gene expression for the two molecules is regulated by afferent activity. Therefore, the present results form a necessary basis for studies aimed at determining the role of activity-dependent changes in the balance of excitation and inhibition as a mechanism under-

Received May 6, 1993; revised July 14, 1993; accepted July 20, 1993.

This work was supported by Grant NS 21377 from the National Institutes of Health, U.S. Public Health Service. We thank Dr. M. B. Kennedy for the antibody to CAM II kinase- $\alpha$, Phong Ngyuen and Hao Truong for technical help, and Drs. S. Akbarian, S. H. C. Hendry, M. M. Huntsman, and P. J. Isackson for their many contributions.

Correspondence should be addressed to Dr. E. G. Jones at the above address.

aPresent address: Department of Neurobiology, Mt. Sinai School of Medicine, New York, NY 10029.

'Present address: Department of Neuroscience, University of Virginia School of Medicine, Charlottesville, VA 22908.

Copyright (C) 1994 Society for Neuroscience $0270-6474 / 94 / 140611-19 \$ 05.00 / 0$ lying plasticity of representational maps in the primate sensory-motor cortex.

[Key words: in situ hybridization histochemistry, spiny neurons, glutamate, synaptic plasticity]

Protein phosphorylation plays a key role in many aspects of neuronal function (Nestler and Greengard, 1984; Browning et al., 1985; Hanson and Schulman, 1992b; Bliss and Collingridge, 1993; Greengard et al., 1993; Raymond et al., 1993), and in the CNS, protein kinases regulated by second messengers such as calcium, cyclic nucleotides, or phospholipids show regional patterns of distribution that may reflect particular functional roles (Kennedy, 1983; Ouimet et al., 1984; Erondu and Kennedy, 1985; Nairn et al., 1985; Worley et al., 1986; Fukunaga et al., 1988; Walaas et al., 1988). One of the most abundant is type II calcium/calmodulin-dependent protein kinase (CAM II kinase; Bennett et al., 1983; Goldenring et al., 1983), a member of a large family of calcium-regulated protein kinases with wide substrate specificity (McGuinness et al., 1983; Shenolikar et al., 1986; Schulman, 1988; Colbran et al., 1989a,b; Lou and Schulman, 1989). This multifunctional protein kinase is a holoenzyme composed of different proportions of $50 \mathrm{kDa} \alpha$ and 58$60 \mathrm{kDa} \beta$ subunits that may exist as hetero- (Bennett et al., 1983; Goldenring et al., 1983; Woodgett et al., 1983) or homopolymers (Kanaseki et al., 1991). The $\alpha$ and $\beta$ subunits are products of different genes (Bennett and Kennedy, 1987; Hanley et al., 1987; Lin et al., 1986; Bulleit et al., 1988) and are expressed in different ratios in the forebrain and brainstem (McGuinness et al., 1985; Miller and Kennedy, 1985; Kanaseki et al., 1991; Yamauchi et al., 1991). In the forebrain of the rat, the enzyme is made up of $\alpha$ and $\beta$ subunits in the ratio of approximately 9:3, with the $\alpha$ subunit comprising approximately $1 \%$ of all forebrain protein (Erondu and Kennedy, 1985). In the brainstem and cerebellum of the rat, the $\beta$ subunit predominates over the $\alpha$ subunit in a ratio of approximately $8: 2$; mRNA levels for the subunits generally parallel protein levels (Burgin et al., 1990; Beaman-Hall et al., 1992). A $\beta^{\prime}$ subunit, structurally related to the $\beta$ subunit and apparently produced from a differentially spliced transcript of the same gene, is found in small quantities mainly in the cerebellum (Bulleit et al., 1988). The retina contains only the $\alpha$ subunit (Bronstein et al., 1988). $\gamma$ and $\delta$ subunits with limited distributions have recently becn described (Tobimatsu et al., 1988; Tobimatsu and Fujisawa, 1989; Takaishi et al., 1992).

CAM II kinase is expressed only in neurons, not in neuroglial cells (Ouimet et al., 1984; Erondu and Kennedy, 1985; Hanley 
et al., 1987; Scholz et al., 1988; Burgin et al., 1990; Benson et al., 1991a,b, 1992a). It is found in both particulate and cytosolic fractions (Sahyoun et al., 1985; Bezmahouta et al., 1987) and is localized both pre- and postsynaptically (Ouimet et al., 1984). Presynaptically, the enzyme phosphorylates synapsin I, causing it to dissociate from synaptic vesicles, thus facilitating the movement of the vesicles toward the presynaptic membrane and facilitating transmitter release (Llinás et al., 1985, 1991; Schiebler et al., 1986; McGuinness et al., 1989; Benferati et al., 1990, 1992; Hackett et al., 1990; Lynn et al., 1990; Nichols et al., 1990, 1992). Postsynaptically, the $\alpha$ subunit of CAM II kinase is associated with the postsynaptic densities of asymmetric synapses and is described as the major postsynaptic density protein (Kennedy et al., 1983a; Goldenring et al., 1984; Kelly et al., 1984). A structurally similar but different protein has also been reported as the major postsynaptic density protein ( $\mathrm{Wu}$ et al., 1992). Recently, CAM II kinase has been shown to be involved in the induction of long-term potentiation in hippocampal pyramidal cells (Malenka et al., 1989; Malinow et al., 1989), and transgenic mice lacking the gene for the $\alpha$ subunit show a lack of inducible long-term potentiation in hippocampal pyramidal cells studied in vitro (Silva et al., 1992a). Behaviorally, the mice show a deficiency in putatively hippocampal-based, spatial memory learning (Silva et al., 1992b). In the neocortex, gene expression for the $\alpha$ and $\beta$ subunits is developmentally regulated (Burgin et al., 1990; Sugiura and Yamauchi, 1992), and in the visual cortex of adult monkeys gene expression for the $\alpha$ subunit is under the control of afferent activity: when impulse activity entering the visual cortex is reduced, mRNA levels for CAM II kinase- $\alpha$ rapidly rise (Benson et al., 1991a). By contrast, increased cortical activity associated with kindled epileptiform seizures in rats leads to reduced CAM II kinase- $\alpha$ mRNA levels (Bronstein et al., 1992).

In previous investigations, primarily on the diencephalon, basal ganglia, and brainstem of monkeys and rats (Benson et al., 1991 b, 1992a), it was discovered that CAM II kinase- $\alpha$, with few exceptions, is expressed only in neurons that are known or reputed to use excitatory amino acid transmitters. This cellspecific expression implies that CAM II kinase- $\alpha$ will be found associated with the pre- and postsynaptic sides of certain synapses, with the pre- or postsynaptic sides but not both of other synapses, and will be absent from both sides in yet other synapses.

In the cerebral cortex, the association of CAM II kinase- $\alpha$ with excitatory amino acid producing neurons has not been so clearly made. In the visual cortex of monkeys immunoreactivity for the $\alpha$ subunit (Hendry and Kennedy, 1986) has been described in large pyramidal cells, which would suggest such a relationship. However, immunoreactivity was also described in small round neurons, which could have included representatives of the several classes of inhibitory interneurons of the cortex in which the transmitter is GABA (reviewed in Houser et al., 1984; Jones et al., 1993). While immunocytochemical localization of GABA and its synthesizing enzyme, glutamic acid decarboxylase (GAD), has played a significant role in defining the various subclasses of neocortical interneurons (Ribak, 1978; Houser et al., 1983, 1984), studies based on immunocytochemistry for glutamate or aspartate have been less successful in characterizing the excitatory neurons of the cerebral cortex. Thus, if the association of CAM II kinase- $\alpha$ with excitatory amino acid transmission can be confirmed, CAM II kinase- $\alpha$ will prove to be a useful marker for the neurochemical identity of cortical excit- atory neurons. In the present investigation, the primary somatosensory and motor areas of the monkey cerebral cortex have been chosen for investigation not only because of the paucity of data available on these areas but also because they are areas that display marked activity-dependent plasticity of representational maps (Merzenich et al., 1983a,b; Clark et al., 1988; Donoghue and Sanes, 1988; Donoghue et al., 1990; Jenkins et al., 1990; Garraghty and Kaas, 1991; Jacobs and Donoghue, 1991; Pons et al., 1991). Activity-dependent regulation of CAM II kinase- $\alpha$, as previously demonstrated in the monkcy visual cortex (Hendry and Kennedy, 1986; Benson et al., 1991a), could be a contributing factor to this plasticity. The present study will serve as a baseline for experimental studies on the subject.

\section{Materials and Methods}

This investigation was carried out on the pre- and postcentral gyri from one or both sides of 12 macaque monkeys aged from 2 to 7 years. Forming part of the study were four Macaca mulatta, four Macaca fuscata, and four Macaca fascicularis. The gyri of four hemispheres came from animals that had been subjected to monocular visual deprivation (Benson et al., 1991a) but that were otherwise normal; those from the remaining hemispheres came from unoperated animals.

The animals were perfused under deep Nembutal anesthesia with normal saline followed by $2 \%$ paraformaldehyde and $0.1 \%$ glutaraldehyde or $4 \%$ paraformaldehyde in 0.1 m phosphate buffer ( $\mathrm{pH} 7.4)$. The brains were removed and postfixed in $2 \%$ or $4 \%$ paraformaldehyde in $0.1 \mathrm{M}$ phosphate buffer. Thereafter, they were infiltrated with $30 \% \mathrm{su}$ crose in $0.1 \mathrm{M}$ phosphate buffer, blocked, and frozen in dry ice. Serial frozen sections were cut either in the parasagittal plane across the central sulcus, or in a plane parallel to the surface of the lateral aspects of the pre- and postcentral gyri. Most sections were cut at 20 or $25 \mu \mathrm{m}$ on a sliding microtome. In selected blocks short series of thinner sections, 10 or $15 \mu \mathrm{m}$ thick, were cut at intervals in the series of thicker sections

Adjacent 20 or $25 \mu \mathrm{m}$ sections from the brains fixed in $2 \%$ paraformaldehyde and $0.1 \%$ glutaraldehyde were stained immunocytochemically by the immunoperoxidase method for CAM II kinase- $\alpha$ or for GABA, histochemically for cytochrome oxidase (CO) (Wong-Riley, 1979 ), or with thionin. The thinner 10 or $15 \mu \mathrm{m}$ sections were stained by double immunofluorescence. Adjacent 20 or $25 \mu \mathrm{m}$ sections from brains fixed in $4 \%$ paraformaldehyde were subjected to in situ hybridization histochemistry to localize CAM II kinase- $\alpha$ or GAD mRNAs, or were stained for $\mathrm{CO}$ or with thionin.

For immunoperoxidase staining, sections were washed in three changes of $0.1 \mathrm{M}$ phosphate buffer and then incubated for $2 \mathrm{hr}$ at $4{ }^{\circ} \mathrm{C}$ in $5 \%$ normal rabbit serum in $0.1 \mathrm{M}$ phosphate buffer containing $3 \%$ Triton $\mathrm{X}-100$. After washing in phosphate buffer, they were reincubated in a $1: 250$ solution of mouse ascites fluid containing a monoclonal antibody of demonstrated specificity for CAM II kinase- $\alpha$ (Erondu and Kennedy, 1985 ) for $24 \mathrm{hr}$ at $4^{\circ} \mathrm{C}$. After repeated washing in phosphate buffer, they were either treated for $2 \mathrm{hr}$ in horseradish peroxidase-conjugated rabbit anti-mouse immunoglobulin (DAKO) or by the avidin-biotin-peroxidase (ABC) method using Vectastain kits, followed by development of a reaction product in 3,3'-diaminobenzidine tetrahydrochloride and $0.01 \%$ hydrogen peroxide. Other sections were preincubated in $5 \%$ normal serum and 3\% Triton X-100 in $0.1 \mathrm{M}$ phosphate buffer, followed by washing and reincubation in a rat anti-G $\Lambda \mathrm{B} \Lambda$ monoclonal antibody (Eugene Tech; 1:1000), a rabbit anti-GABA antiserum (Chemicon, 1:3000), a mouse anti-GABA monoclonal antibody (Matute and Streit, $1986 ; 1: 7500$ ), or a rabbit anti-GABA antiserum (Sigma; 1:10,000). The antibodies or antisera were diluted in $0.1 \mathrm{M}$ phosphate buffer containing $0.2 \%$ Triton $\mathrm{X}-100$ and $3 \%$ normal serum from the species in which the secondary antibodies to be used had been made. After incubation for $12-48 \mathrm{hr}$ at $4^{\circ} \mathrm{C}$, sections were washed and transferred to unlabeled, swine anti-rabbit (DAKO), or biotinylated goat anti-rabbit, rabbit antirat, or goat anti-mouse (Vector) secondary immunoglobulins for 1-2 hr. Thereafter, they were washed and processed using either rabbit peroxidase-antiperoxidase complex (DAKO; 1:200) or Vectastain kits and the diaminobenzidine reaction. All processing was done on free-floating sections that were later mounted on gelatin-coated slides, dehydrated, cleared, and coverslipped.

Control sections from the same blocks were incubated in ascites fluid from a non-immunoglobulin-secreting mouse tumor or in anti-GABA 

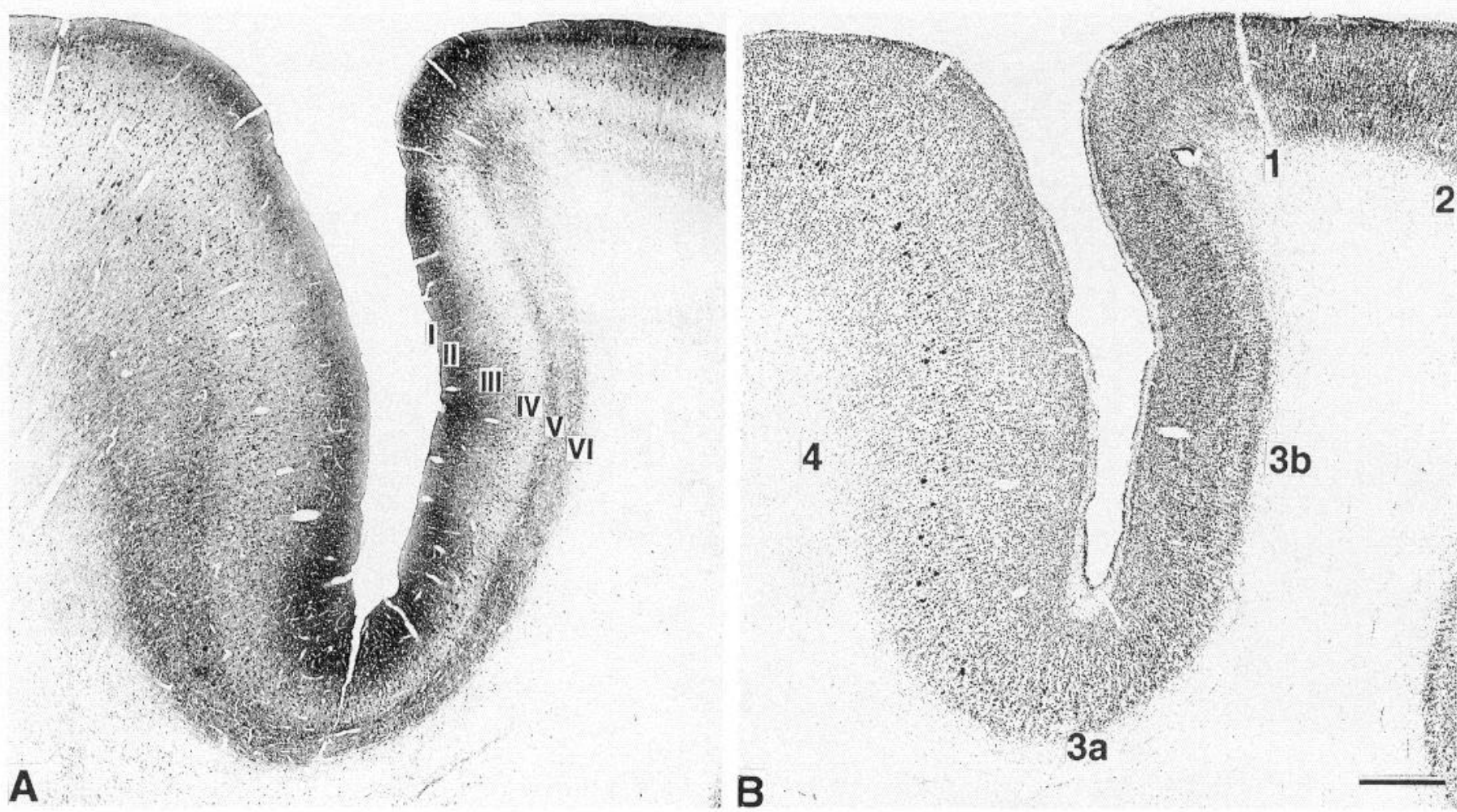

Figure 1. Adjacent parasagittal sections stained immunocytochemically for CAM II kinase- $\alpha(A)$ and with thionin $(B)$, showing laminar concentrations of CAM II kinase- $\alpha$ immunoreactivity. The densest staining is in layers II, upper III, upper V, and VI; staining of larger pyramidal cells is visible in layers III and V of areas 4,1 , and 2 . In the somatic sensory areas, layer IV appears unstained at this magnification, but compare with Figure 6. Scale bar, $1 \mathrm{~mm}$.

antibody or antiserum that had been preadsorbed with an excess (15$45 \mu \mathrm{g} / \mathrm{ml}$ ) of GABA or with a GABA-bovine serum albumin conjugate (Matute and Streit, 1986). Under these conditions, no specific immunostaining could be identified.

Selected groups of sections cut at 10 or $15 \mu \mathrm{m}$ were double stained by indirect immunofluorescence for both GABA and CAM II kinase$\alpha$. Sections were preincubated in $0.1 \mathrm{M}$ phosphate buffer containing $3 \%$ normal serum and $0.25 \%$ Triton $\mathrm{X}-100$ for $1 \mathrm{hr}$ at $4^{\circ} \mathrm{C}$. They were then incubated in a mixture of rabbit anti-GABA antiserum (Sigma; 1:5000) and the same mouse anti-CAM II kinase- $\alpha$ monoclonal antibody as above $(1: 1000)$ in the same buffer overnight at $4^{\circ} \mathrm{C}$. Sections were then washed in phosphate buffer and incubated successively in fluorescein isothiocyanate-conjugated anti-rabbit IgGs and in rhodamine isothiocyanate-conjugated anti-mouse IgGs (Caltag Inc.) for $2 \mathrm{hr}$ at $4^{\circ} \mathrm{C}$. Sections were washed in phosphate buffer, mounted on slides in $60 \%$ glycerol in phosphate buffer, and examined under epifluorescence microscopy with fluorescein and rhodamine excitation filters. Adjacent sections were stained with thionin.

Sections for in situ hybridization histochemistry were hybridized to sense and antisense GAD or CAM II kinase- $\alpha$ riboprobes derived from monkey-specific cDNAs. The generation of the cDNAs from RNA of monkey cerebral cortex has been described elsewhere (Benson et al., 1991a). The GAD cDNA is a 365 nucleotide sequence encoding a portion of the $67 \mathrm{kDa}$ GAD protein. The CAM II kinase- $\alpha$ cDNA is a 375 nucleotide sequence $95 \%$ homologous to a rat CAM II kinase- $\alpha$ cDNA (Lin et al., 1987), but with a 33 nucleotide insert. Sense and antisense cRNA probes were transcribed from pBluescribe (Stratagene) clones in the presence of $\alpha-{ }^{35} S$-UTP. The specificity of the probes has previously been demonstrated (Benson et al., 1991a).

Free-floating sections were pretreated with $1 \mu \mathrm{g} / \mathrm{ml}$ proteinase $\mathrm{K}$, $0.25 \%$ acetic anhydride in $0.1 \mathrm{~m}$ triethanolamine $(\mathrm{pH} 8)$, and $2 \times$ salinesodium citrate (SSC) for $30 \mathrm{~min}$ at $30^{\circ} \mathrm{C}$. They were treated in prehybridization buffer containing $50 \%$ deionized formamide, $10 \%$ dextran sulfate, $0.7 \%$ Ficoll, $0.7 \%$ polyvinyl pyrolidone, $0.7 \%$ bovine serum albumin, $0.15 \mathrm{mg} / \mathrm{ml}$ yeast tRNA, $0.33 \mathrm{mg} / \mathrm{ml}$ denatured herring sperm DNA, and $20 \mathrm{~mm}$ dithiothreitol (DTT) for $1 \mathrm{hr}$ at $60^{\circ} \mathrm{C}$. Sections were then transferred to a fresh solution of the same buffer with the addition of $20 \mathrm{~mm}$ DTT and $1 \times 10^{4} \mathrm{cpm} / \mu$ l of the ${ }^{35} \mathrm{~S}$-labeled riboprobe, and incubated for at least $20 \mathrm{hr}$ at $60^{\circ} \mathrm{C}$. After hybridization, sections were washed briefly in $4 \times$ SSC, treated with $20 \mu \mathrm{g} / \mathrm{ml}$ ribonuclease A for 30 $\min$ at $45^{\circ} \mathrm{C}$, and then washed in progressively decreasing concentrations of SSC down to a final stringency of $0.1 \times \mathrm{SSC}$ at $60^{\circ} \mathrm{C}$ for $1 \mathrm{hr}$.

Sections were mounted on gelatin-coated slides, dried, and exposed to Amersham $\beta \max$ film for $1-4 \mathrm{~d}$. After development of the film autoradiogram, the sections were lipid extracted in chloroform, dipped in Kodak NTB-2 emulsion diluted 1:1 in water, exposed for 7-15 d at $4^{\circ} \mathrm{C}$, and then developed in Kodak D19, fixed, and stained through the emulsion with cresyl violet.

Sense-strand riboprobes on control sections revealed no hybridization above background (see Results).

For consistency and to serve as a baseline for future experimental studies, all analyses were carried out on the putative upper limb representations of the primary motor (MI) and somatosensory (SI) areas, that is, a region of the pre- and postcentral gyri stretching from a line joining the pre- and postcentral sulci to a parallel line running through the tip of the intraparietal sulcus. Sections were analyzed qualitatively, relating the distributions of immunostained cells or patterns of riboprobe hybridization to cytoarchitectonic areas and cortical layers as seen in adjacent CO- and Nissl-stained sections, and quantitatively by cell counts and optical density measurements. Sections stained for double immunofluorescence were examined qualitatively for the presence or absence of double-labeled cells.

Cell counts were made on sections stained by the immunoperoxidase method for GABA or CAM II kinase- $\alpha$ or with thionin. Stained cells were counted in $50-\mu \mathrm{m}$-wide columns spanning the thickness of areas $4,3 \mathrm{a}, 3 \mathrm{~b}, 1$, and 2 and extending from pia mater to $200 \mu \mathrm{m}$ into the white matter subjacent to layer VI. At least five columns were counted from each section and at least five sections were analyzed from each brain. Counts were made directly from the microscope, using an eyepiece reticle that at a magnification of $1250 \times$ delineated a narrow column $50 \mu \mathrm{m}$ wide and had bars along its length at $5 \mu \mathrm{m}$ intervals. This columnar reticle was placed over the cortex in the line of the radial fasciculi and stepped as necessary across the thickness of the cortex. Only stained cell somata greater than $8 \mu \mathrm{m}$ in diameter were counted, 


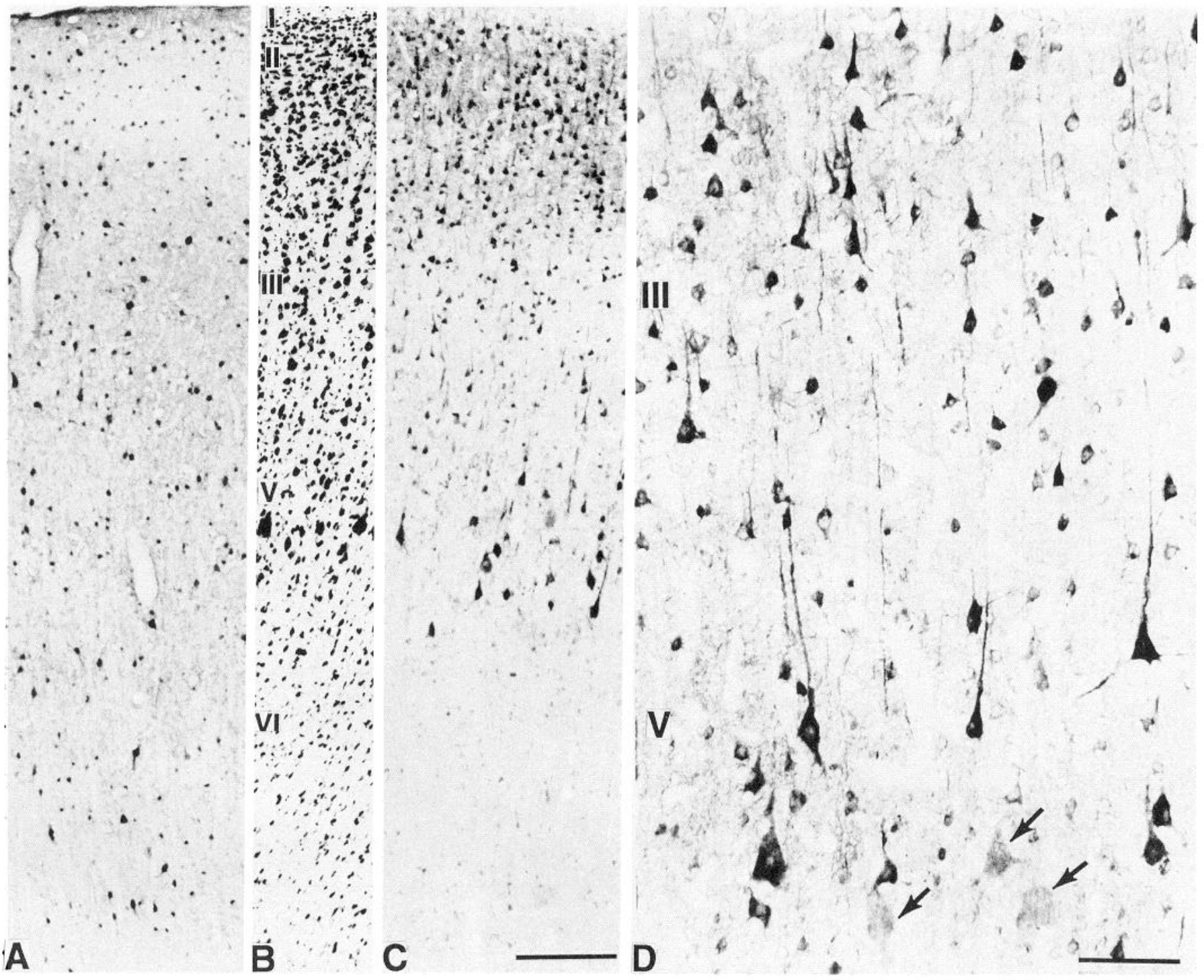

Figure 2. $A-C$, Portions of adjacent sections through the thickness of area 4 showing immunoreactive staining for GABA $(A)$ and CAM II kinase$\alpha(C)$. Layers II and upper III show densest staining when compared with the thionin-stained lamination pattern $(B)$. Layer VI shows weak CAM II kinase- $\alpha$ immunostaining of many cells (compare Fig. $4 A$ ). Scale bar, $250 \mu \mathrm{m}$. $D$, Higher-magnification view of adjacent parts of layers III and $\mathrm{V}$ from another section stained for CAM II kinase- $\alpha$ immunoreactivity. Staining of pyramidal cells as well as of smaller cell somata is evident. Many Betz cells (arrows) are only weakly immunoreactive. Scale bar, $100 \mu \mathrm{m}$.

since previous studies (Hendry et al., 1987) showed that this is the lower limit of size of neurons cut through the nucleus in these cortical areas. Cell profiles touching the left side of the reticle were counted, those touching the right side were not.

A similar strategy was adopted for counting GAD-expressing cells in in situ hybridization preparations; in these, dense concentrations of silver grains overlying cell nuclei and visualized in reverse contrast under dark-field illumination were counted in $50-\mu \mathrm{m}$-wide columns through the thickness of the cortical areas. The diffuse and dense nature of the hybridization signal in preparations hybridized for CAM II kinase- $\alpha$ mRNA precluded similar counts of CAM II kinase- $\alpha$ expressing cells.

Optical density measurements were also made in 50- $\mu \mathrm{m}$-wide columns across the thickness of each area of the sensory-motor cortex in the digitized film autoradiograms, using the transept tool of the MCID M4 imaging system (Imaging Research, St. Catherine's, Canada). Readings were converted to measures of radioactivity by reference to density readings made on ${ }^{14} \mathrm{C}$ plastic standards (Amersham) exposed on the same piece of film. Background was subtracted on the basis of readings made over deep white matter. Peaks and valleys of optical density were related to layers of the cerebral cortex by matching to similarly digitized images of adjacent thionin- or CO-stained sections.

\section{Results}

Laminar distribution of CAM II kinase- $\alpha$ immunoreactive cells

Area 4. Layer I contains no immunoreactive cells but shows a relatively high intensity of neuropil staining overall (Figs. 1, 2), commonly with $\mathrm{Y}$-shaped stained processes resembling the branching apical dendrites of pyramidal cells embedded in its deeper half (Fig. 3). Layer II and the superficial half of layer III also show dense neuropil staining and contain many densely immunoreactive cells, commonly with triangular cell bodies, $15-18 \mu \mathrm{m}$ in diameter, and stained proximal portions of apical and basal dendrites. The density of neuropil staining and the number of stained cells decline somewhat in deeper layers. In deep layer III moderate numbers of well-stained pyramidal cells with medium- and small-sized somata and clearly discernible apical dendrites are present, along with a relatively high number of more weakly stained small, angular, or round somata 10-12 


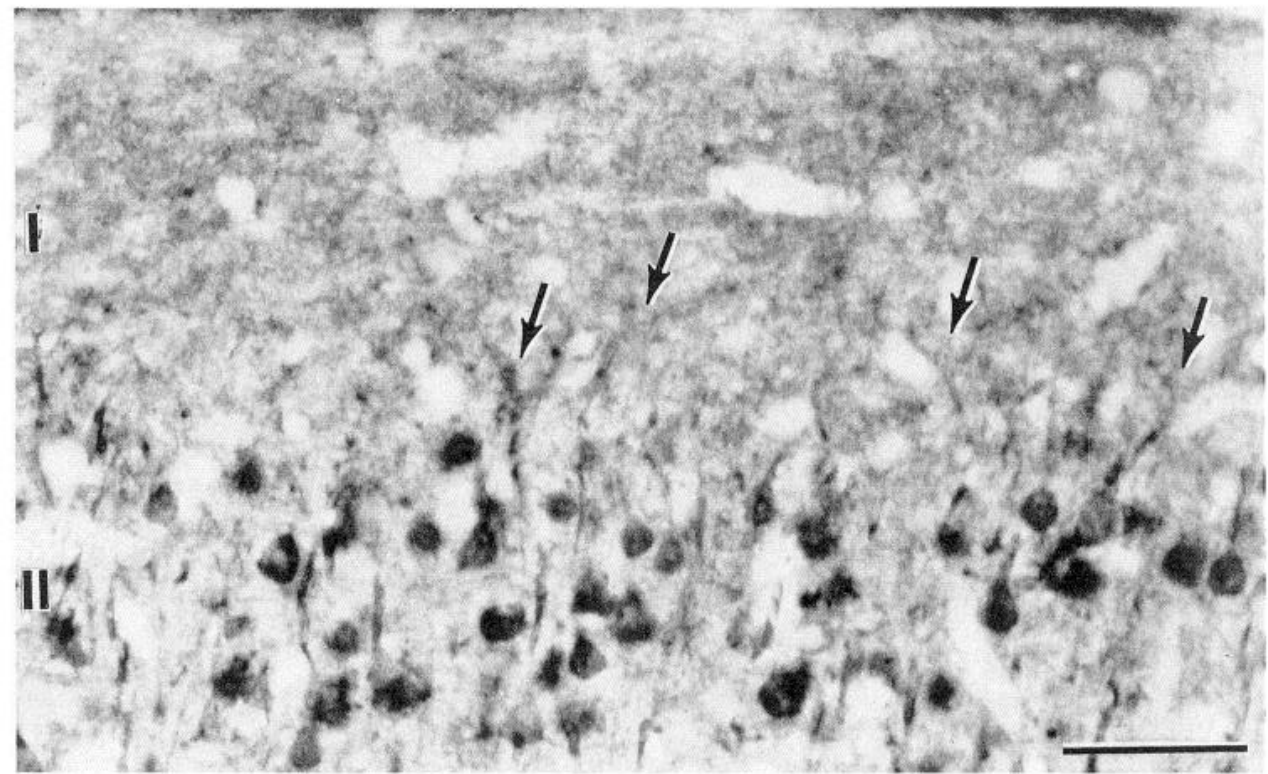

Figure 3. Immunoreactive staining for CAM II kinase- $\alpha$ in layers I and II of area 4 . There is only neuropil staining in layer I and branching of immunoreactive apical dendrites (arrows) can be detected. Scale bar, $50 \mu \mathrm{m}$. $\mu \mathrm{m}$ in diameter, with the proximal portions of their dendrites. In layer V, the giant somata of the Betz cells are clearly stained and form a continuous line across the precentral gyrus and down the anterior bank of the central sulcus (Fig. 1A). However, most are weakly stained in comparison with other pyramidal cells in layer V (Fig. 2D) and only the most proximal parts of their dendrites are stained. By contrast, other pyramidal cells with medium- and small-sized somata in layer $\mathrm{V}$ are intensely immunostained and their apical and basal dendrites are commonly stained over relatively long distances (Fig. 2D). Layer V shows some slight enhancement of neuropil staining so that at low magnification a thin continuous line of enhanced staining is seen more or less coextensive with the line of Betz cell somata (Fig. $1 A)$.

A large number of immunoreactive cells are stained in layer $\mathrm{V}$ deep to the Betz cells and in layer VI. However, with few exceptions the cells are weakly stained (Fig. $2 C$ ) with round or oval somata and only rarely with a stained apical dendrite. A few more intensely stained cells situated mainly in the deep part of layer VI are multipolar in form and resemble the peptideimmunoreactive cells of the layer (Hendry et al., 1984a,b; Jones et al., 1988). A moderate number of lightly immunoreactive cell somata is also seen scattered through the subcortical white matter 200-300 $\mu \mathrm{m}$ deep to layer VI (Fig. 4A).

Areas $3 a, 3 b, 1$, and 2 . The most conspicuous feature of these areas at low magnification (Fig. $1 A$ ) is the presence of a continuous pale line, thin in area $3 \mathrm{a}$, thick in area $3 \mathrm{~b}$, and thinning again in areas 1 and 2, and more or less coextensive with layer IV in adjacent thionin- and CO-stained sections. Although apparently bereft of immunoreactivity at low magnification (Figs. $1 A, 5$ ), inspection at higher magnification (Fig. 6) reveals this layer IV band to be full of small, round, weakly immunoreactive somata $10-12 \mu \mathrm{m}$ in diameter. Even qualitatively, however, their numbers clearly do not account for the full neuronal population of layer IV.

The general laminar pattern of CAM II kinase- $\alpha$ cell distribution is very similar in each of the four areas of the postcentral gyrus (Figs. 1, 5). There are no immunoreactive cells in layer I, although this layer shows dense neuropil staining overall and staining of branching apical dendrites in its deeper half, as in area 4. In layer II and upper layer III, many small cells are stained; most can be identified as pyramidal on the basis of somal shape, a feature that becomes particularly overt in areas 1 and 2. There is a slight decline in the number of stained cells in the middle of layer III, particularly in area $3 \mathrm{~b}$ (Fig. $5 \mathrm{C}$ ), but the number of stained cells increases again in the deeper aspect of layer III. There, most stained cells have medium-sized pyramidal somata with prominent apical dendrites. A few smaller pyramidal cells are also stained in deep layer III. The staining of cells in this sublayer shades into layer IV, in which most of the small, round, weakly stained somata characteristic of the layer are found in the upper half and extend among the more intensely stained pyramidal cells of deep layer III. The concentration of the weakly stained layer IV cells in the upper part of the layer is particularly overt in areas 1 and 2 (Fig. $5 F$ ). In layer $\mathrm{V}$, mainly large- and medium-sized pyramidal cells with prominent apical dendrites are stained and form a single continuous line, embedded in a line of slightly enhanced neuropil staining, through all four areas. Although invariably well stained, their numbers are remarkably few in areas $3 a$ and $3 b$ and, even qualitatively, they cannot account for the full population of largeand medium-sized pyramidal cells in layer $\mathrm{V}$ of those areas. Their numbers increase somewhat in areas 1 and 2. Layer VI of all four areas is filled with large numbers of relatively weakly stained, round or oval somata and the staining resembles that in layer VI of area 4. Similarly, modest numbers of immunoreactive small cells are found in the subcortical white matter. The deeper white matter is filled with immunoreactive fibers of medium (ca. $5 \mu \mathrm{m})$ and large $(10 \mu \mathrm{m})$ diameter.

\section{Laminar distribution of GABA-immunoreactive cells}

The pattern of distribution of GABA-immunoreactive cells has previously been described in detail in areas $4,3 \mathrm{~b}$, and in areas 1 and 2 (together) (Hendry et al., 1987). Only a few additional points, therefore, need be made here. GABA-immunoreactive cells are found in all layers of areas $4,3 a, 3 b, 1$, and 2 . In area 4 (Fig. $2 A$ ), they are relatively widely scattered with occasional localized aggregations but there is no distinct laminar distribution. Small immunoreactive somata $10-12 \mu \mathrm{m}$ in diameter are characteristic of layers I, II, upper III, and upper VI. There 

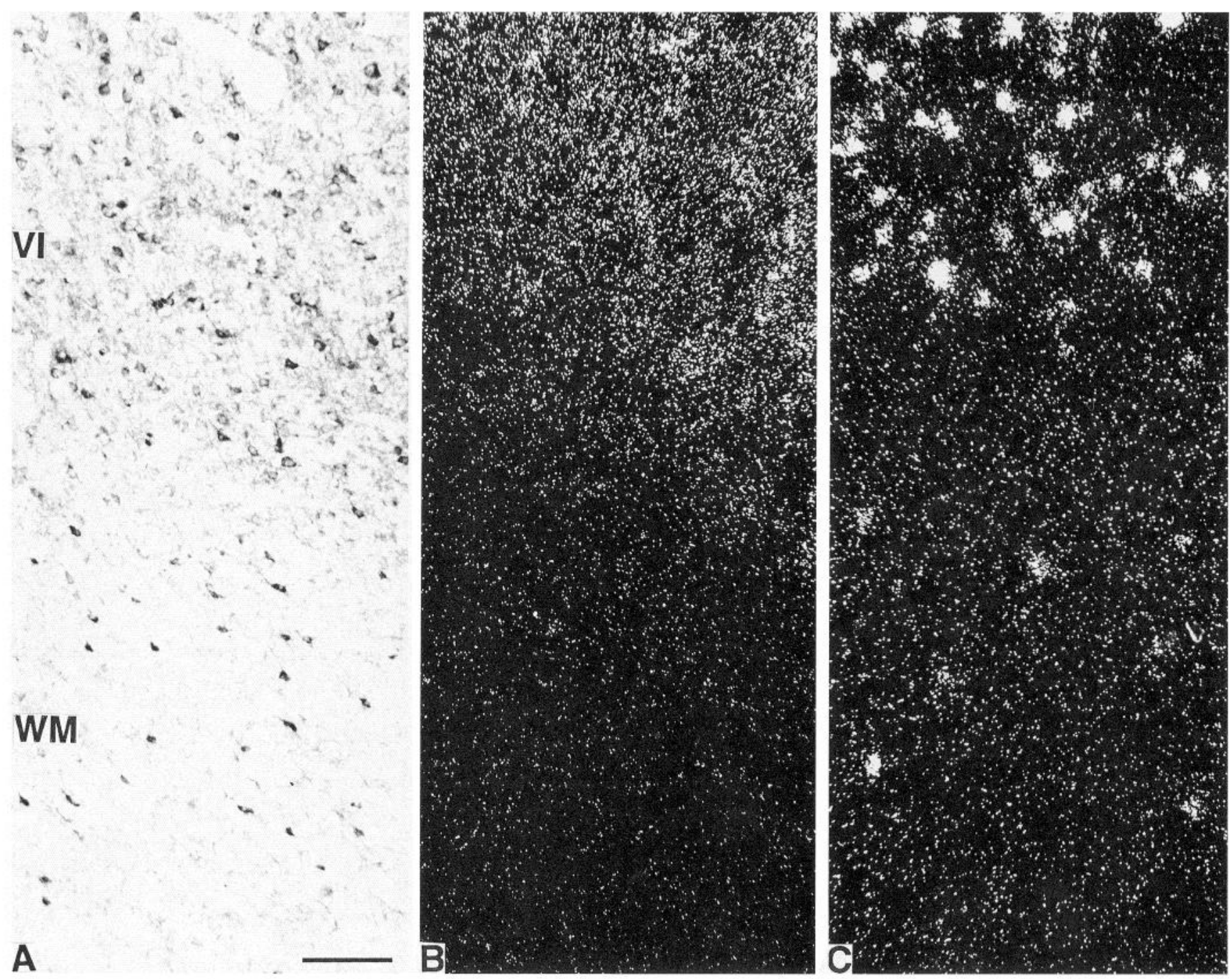

A

Figure 4. A, CAM II kinase- $\alpha$ immunoreactive cells in layer VI of area 4 and in the underlying white matter. $B$, A region comparable to that shown in $A$ but from a section showing in situ hybridization of a radioactive cRNA probe to CAM II kinase- $\alpha$ mRNA. Labeling of the neuropil of layer VI is characteristically high (compare Figs. 8-12). By contrast with $A$, no cells are labeled in the white matter. $C$, Comparable part of the section adjacent to that shown in $B$ but showing hybridization of a radioactive GAD-67 cRNA probe. The clear labeling of somata is typical. Many cells are labeled in the white matter. Scale bar, $50 \mu \mathrm{m}$.

are large (15-20 $\mu \mathrm{m})$ and small immunoreactive somata mixed together across deep layer III and layer V, although most of the larger cells are found in layer III. Deep layer VI contains both small- and medium-sized $(10-15 \mu \mathrm{m})$ immunoreactive somata and there is a small but very distinct population of small- to medium-sized immunoreactive somata in the immediate subcortical white matter.

Areas $3 \mathrm{a}$ and $3 \mathrm{~b}$ (Fig. $5 \mathrm{~A}$ ) show a more distinct laminar pattern of distribution, with increased numbers of immunoreactive cells in layer II, in deep layer III and upper layer IV, and in deep layer V or upper layer VI. Much of layer IV and deep layer VI appear as pale-stained lines when viewed at low magnification. Deep layer III and upper layer IV are dominated by relatively large numbers of large $(15-20 \mu \mathrm{m})$ immunoreactive somata embedded in a densely immunoreactive neuropil, along with moderate numbers of smaller immunoreactive cells. Area $3 \mathrm{a}$ is dominated by the large immunoreactive cells as its middle layers fuse in the floor of the central sulcus. The deeper half of layer IV in area 3 b contains remarkably few GABA-immunoreactive cells.

In areas 1 and 2 (Fig. 5D), the laminar pattern resembles that in area $3 \mathrm{a}$ except that the unstained band of deep layer IV is not present and the smaller immunoreactive cells of layers III and V merge across layer IV. Large immunoreactive somata remain prominent in deep layer III.

In the white matter immediately deep to layer VI of all areas, there is a small number of small GABA-immunoreactive somata.

\section{Double immunofluorescent staining for GABA and CAM II kinase- $\alpha$}

All layers of all areas were sampled in sections stained by double immunofluorescence for GABA and CAM II kinase- $\alpha$. No example of a double-labeled cell was found. In all cases separate cells are stained. Those stained for GABA (Fig. 7A,C,E) can clearly be identified as nonpyramidal by the shape of the somata 

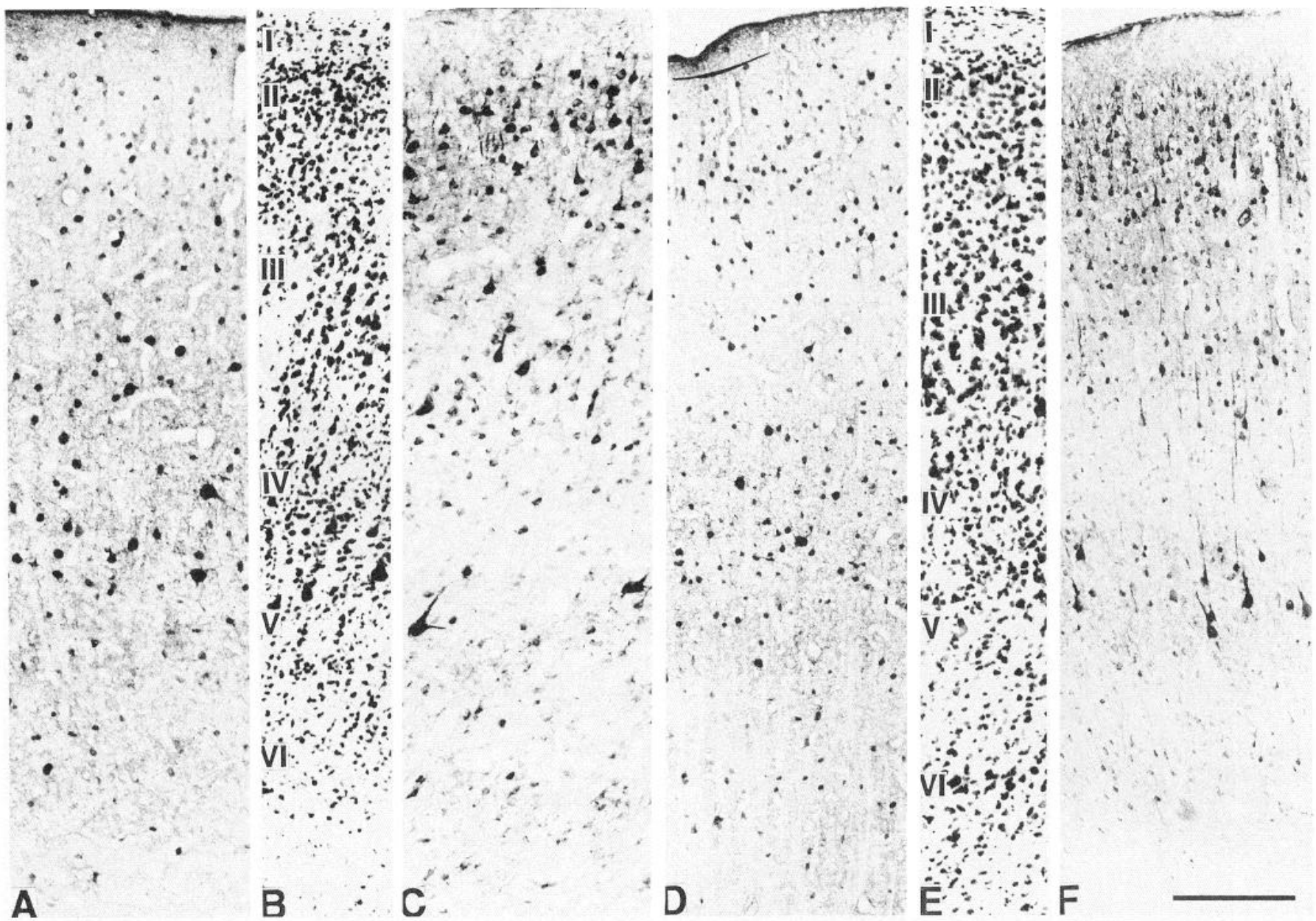

Figure 5. Photomicrographs through the thickness of the cortex of areas $3 \mathrm{~b}(A-C)$ and $1(D-F)$, stained immunocytochemically for GABA $(A$, $D$ ) or for CAM II kinase- $\alpha(C, F)$ or with thionin $(B, E)$. GABA cells are stained in all layers, with both large and small stained somata visible in layer IV. CAM II kinase- $\alpha$ cells are stained in layers II-VI but staining of cells in layers IV and VI is weak. Scale bar, $250 \mu \mathrm{m}$.

and the configuration of the proximal dendrites, and fall into the typical large and small somal size categories described in ABC-peroxidase reacted sections. The larger cells that are immunoreactive for CAM II kinase- $\alpha$ in the same immunofluorescent sections almost invariably reveal a pyramidal-shaped soma (Fig. $7 B, D$ ) outlined by GABA-immunoreactive terminal boutons (Fig. $7 A, C$ ). Of particular note, however, is the fact that a considerable number of pyramidal cell somata in all layers, identified as negative images outlined by the GABA-immunoreactive terminals, are definitely not CAM II kinase- $\alpha$ immunoreactive (Fig. $7 C, D$ ). Also of note in deep layer III and upper layer IV of areas $3 a, 3 b, 1$, and 2 , in which the typical large GABA-immunoreactive somata are seen, is the presence among them of large numbers of much smaller, round or ovoid somata that are CAM II kinase- $\alpha$ positive and not co-stained for GABA (Fig. 7E,F).

\section{In situ hybridization histochemistry}

$G A D$. In all areas, GAD-67 hybridized cells can be detected in all layers and in the underlying white matter (Figs. 8A, 9, 10A). Rounded concentrations of silver grains overlie neuronal nuclei (Fig. 11 A) and tend to fall into two general ranges of diameter: large (20-25 $\mu \mathrm{m}$ in diameter) and small to medium (15-20 $\mu \mathrm{m}$ in diameter). It is assumed that these bear a relationship to the sizes of the underlying somata (Benson et al., 1991b) but the destruction of stainable Nissl substance by the RNase treatment of the sections renders the somata, apart from the nucleus, largely invisible. The nuclei of neuroglial cells are clearly stained (Fig. 11A) and recognizable as such. No silver grains overlie them. Sense probes (Fig. $9 C$ ) showed no hybridization above background.

Area 4. Clusters of grains indicative of labeled cells are scattered throughout the depth of the area (Fig. 12). The only distinct laminar concentration is coextensive with layer II. In all other layers the density of labeled cells is qualitatively similar. There are small- to medium-sized grain concentrations in all layers, including a significant number in the upper half of layer $\mathrm{V}$. In deep layer III there are many large grain concentrations as well, and in layer VI many of the grain concentrations are at the upper end of the small- to medium-diameter range. A significant number of small grain concentrations are found in the underlying white matter, mostly close to layer VI but a few are found at deeper depths as well (Fig. 4).

Areas $3 a, 3 b, 1$, and 2 . These are all distinguished by the presence of a distinct lamina of small- to medium-sized grain concentrations coextensive with layer IV (Fig. 13). In areas 3a and $3 \mathrm{~b}$, it is rendered even more distinct by the presence of thin zones of absent labeling in the parts of layers III and V flanking 


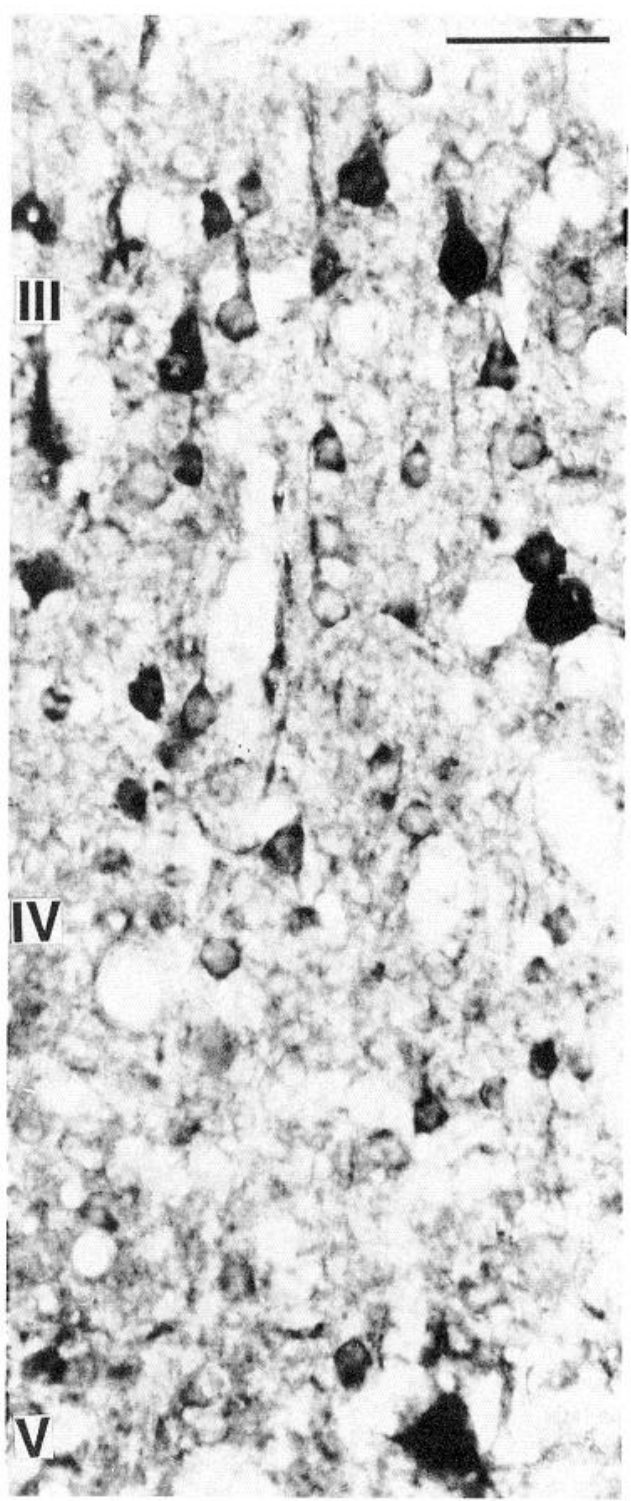

Figure 6. Immunocytochemical staining for CAM II kinase- $\alpha$ in layer IV and adjacent parts of layers III and V of area 1 . In addition to the prominent staining of large and small pyramidal neurons, there is weaker staining of a considerable number of small cell somata, particularly in layer IV (compare Fig. 7). Scale bar, $50 \mu \mathrm{m}$.

layer IV. Layer II also forms a distinct lamina of small to medium grain concentrations. Many large grain concentrations are evident in the deeper aspect of layer III. The large grain concentrations are particularly evident in areas 1 and 2 where layer IV is less distinct as an entity because of large grain concentrations intruding into it from layers III and V. All other layers contain moderate numbers of mainly small- to medium-sized grain concentrations and there are a moderate number in the underlying white matter, distributed as in area 4.

$C A M$ II kinase- $\alpha$. By contrast with preparations hybridized with GAD riboprobes in which distinct grain clusters indicative of individual cell labeling are seen, the appearance of those hybridized with CAM II kinase- $\alpha$ riboprobes is one of diffuse, dense neuropil labeling in which labeling of individual somata is difficult to discern (Figs. $8 B, 10 C, 11 B$ ). The labeling is, however, specific as judged by the presence of laminar differences in density, the lack of more than background in the white matter, and the absence of similar labeling with the sense riboprobes (Fig. 8D). All layers show labeling but that in layer I is particularly low, the graphs (Fig. 10) contrasting with those indicating the GAD labeling in that layer.

Area 4. Neuropil labeling is dense throughout the cortex in comparison with the underlying white matter (Fig. 12). Layer I shows the least dense labeling with no somal labeling; there is also a band of relatively weak labeling coextensive with deep layer V. Layer II and upper layer III show such intense labeling that few independent grain clusters indicative of labeling of somata can be distinguished in it. Labeling becomes relatively less intense in middle layer III and medium to large grain concentrations can now be discerned. The intensity of labeling increases again in deep layer III and upper layer V, where many large grain concentrations are seen. Labeling falls off somewhat in deep layer V and upper layer VI but increases again in deep layer VI to levels approaching those seen in deep layer III and upper layer V. Individual grain concentrations of medium size are seen throughout layer VI. By contrast with the immunoreactive preparations, no grain concentrations indicative of cell labeling by CAM II kinase- $\alpha$ riboprobes are found in the white matter.

Areas $3 a, 3 b, 1$, and 2 . The appearance of labeling is, overall, similar to that in area 4 (Fig. 13). There are zones of absent or much less intense label in layer I and throughout most of layer $\mathrm{V}$ in all four areas. There is dense labeling in layers II-III and VI with particularly intense concentrations in deep layer III and layer IV. Large grain concentrations indicative of somal labeling are evident in deep layer III and layer V, particularly in areas 1 and 2, but are not resolvable elsewhere, except in layer VI, mainly in the film autoradiograms (Fig. 10C). There are no grain concentrations indicative of somal labeling in the underlying white matter.

\section{Cell counts}

Cell somata labeled by immunoreactivity for CAM II kinase$\alpha$ or GABA and by in situ hybridization for GAD-67 were counted in multiple, $50-\mu \mathrm{m}$-wide columns through the thickness of areas $4,3 \mathrm{a}, 3 \mathrm{~b}, 1$, and 2 . The density of neuropil labeling and the difficulty of resolving individual grain concentrations representing underlying labeled somata precluded making similar counts in sections hybridized for CAM II kinase- $\alpha$ mRNA. Counts of labeled cells were matched to those of thionin-stained cells made on adjacent sections. Data are shown in Table 1. GABA-immunoreactive cells show a mean of approximately $31-46$ per $50-\mu \mathrm{m}$-wide column, depending on the area, and form approximately $20-29 \%$ of the total neuronal population. These figures are similar to those previously reported (Hendry et al., 1987).

GABA cells hybridized for GAD-67 mRNA, as counted from the grain concentrations, show slightly higher numbers per 50$\mu \mathrm{m}$-wide column. The mean numbers range from approximately 43 to 51 per column and the labeled cells form approximately $27-31 \%$ of the total neuronal population.

CAM II kinase- $\alpha$ immunoreactive cells show a mean of approximately $54-88$ cells per $50-\mu \mathrm{m}$-wide column, with the highest numbers in area 4 . They form approximately $37-60 \%$ of the total neuronal population in each area studied. The lower means tend to be in areas $3 a$ and $3 b$.

\section{Discussion}

The principal finding of this investigation is that GAD-67 and CAM II kinase- $\alpha$ are clearly expressed in different populations 

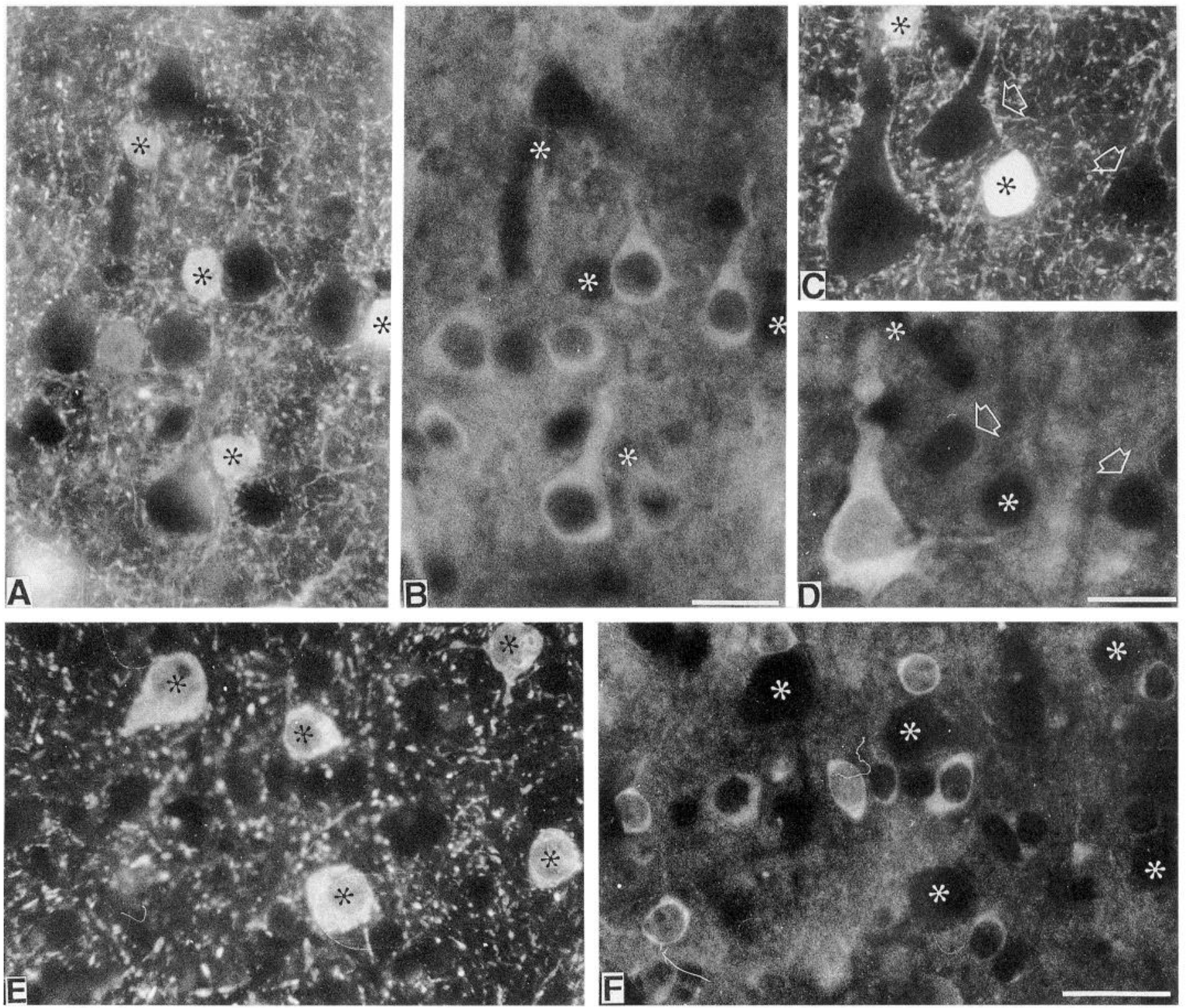

Figure 7. Pairs of fluorescence photomicrographs from the same microscopic fields of sections double stained by fluorescein immunofluorescence for $\operatorname{GABA}(A, C, E)$ and by rhodamine immunofluorescence for CAM II kinase- $\alpha(B, D, F)$. All show lack of colocalization of GABA and CAM II kinase $-\alpha$ immunoreactivity. $A$ and $B$, from layer III of area 1 , and $C$ and $D$, from layer V of area 4 , show labeling of pyramidal cells by CAM I kinase- $\alpha$ immunoreactivity. In $C$ and $D$, however, not all pyramidal cells are CAM II kinase- $\alpha$ positive (arrows). $E$ and $F$, from layer IV of area $3 \mathrm{~b}$, show GABA-positive large cells and CAM II kinase- $\alpha$ positive small cells, both of which are typical of the layer. Asterisks indicate GABApositive cells in each pair. Scale bars, $20 \mu \mathrm{m}$.

of neurons in the monkey sensory-motor cortex. CAM II kinase- $\alpha$ is expressed in pyramidal cells and in certain small nonGABA cells of layer IV. This finding conforms to the previously presented evidence (Benson et al., 1991b, 1992a) for the association of CAM II kinase with neurons that produce excitatory amino acid transmitters. The present results show, however, that CAM II kinase- $\alpha$ expressing cells cannot account for the total non-GABAergic neuronal population in the cerebral cortex and that a certain proportion of the cortical pyramidal cells probably does not express it.

The presence of GAD-67 and CAM II kinase- $\alpha$ in separatc populations of cortical neurons seems clearly evident from the quantitative studies, from the pyramidal morphology of many cells immunoreactive for CAM II kinase- $\alpha$ (GABA cells all being nonpyramidal: Ribak, 1978; Houser et al., 1983, 1984), and from the immunofluorescence staining in which no cells were double labeled for GABA and CAM II kinase- $\alpha$. The pyramidal morphology of many CAM II kinase- $\alpha$ immunoreactive cells tends to confirm the association with excitatory amino acid transmission since it is known that the axon terminals of pyramidal cells projecting to subcortical targets such as the striatum, thalamus, spinal cord, and superior colliculus release glutamate or some related excitatory amino acid (Kim et al., 1977; Storm-Mathisen, 1977; Lund-Karlson and Fonnum, 1978; McGeer et al., 1978; Reubi and Cuénod, 1979; Stone, 1979; Streit, 1980; Canzek et al., 1981; Fonnum et al., 1981; Thangnipon and Storm-Mathisen, 1981; Young et al., 1981; Fonnum, 1984; Ottersen and Storm-Mathisen, 1984). It is assumed that the intracortical collaterals of these axons will also make excitatory synapses, which is in keeping with the typical asymmetric 

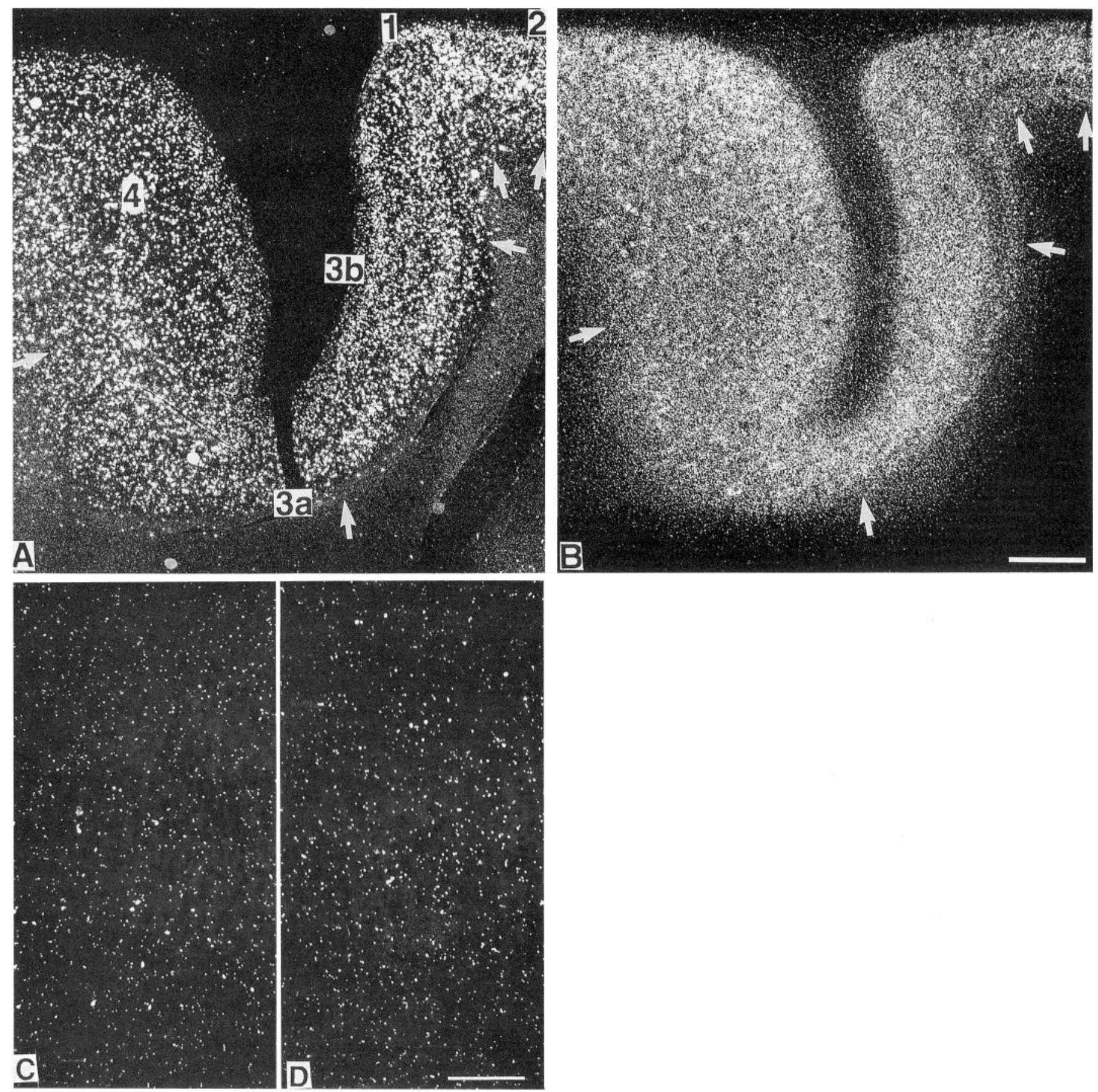

Figure 8. $A$ and $B$, Dark-field photomicrographs from autoradiographs of adjacent sections showing in situ hybridization of GAD $(A)$ and CAM II kinase- $\alpha(B)$ riboprobes. Laminar concentrations of GAD mRNA-containing cells are clearly visible in areas $3 b, 1$, and 2 . CAM II kinase- $\alpha$ hybridization typically shows a high density in the neuropil but laminar concentrations are visible and cell somal labeling can be detected, particularly in layer V of area 4 (compare Figs. 10,14). Scale bar, $1 \mathrm{~mm}$. $C$ and $D$, Autoradiographs from sense controls showing lack of significant hybridization with sense GAD $(C)$ and sense CAM II kinase- $\alpha$ riboprobes. Arrows show positions of traverses made in Figure 9 . Scale bar, $250 \mu$ m.

morphology of their terminals (Winfield et al., 1981; DeFelipe et al., 1988; McGuire et al., 1991). The presence of glutamate immunoreactivity in many pyramidal cells of the monkey sensory-motor cortex (DeFelipe et al., 1988) would tend to confirm the association. Apart from the presence of CAM II kinase- $\alpha$ immunoreactivity in pyramidal cells, its presence in a large population of small non-GABA neurons in layer IV also suggests its association with excitatory neurons. The only population of small non-GABA neurons in the cerebral cortex generally and in layer IV in particular is the population of dendritic spinebearing interneurons, commonly known as spiny stellate cells (Lund, 1984). Their axon terminals are known to have a synaptic morphology of the type customarily associated with excitatory synapses (LeVay, 1973; Kisvárday et al., 1986), that is, round synaptic vesicles and asymmetric membrane thickenings (Colonnier, 1968; Jones and Powell, 1969; Peters and Kaiserman- 

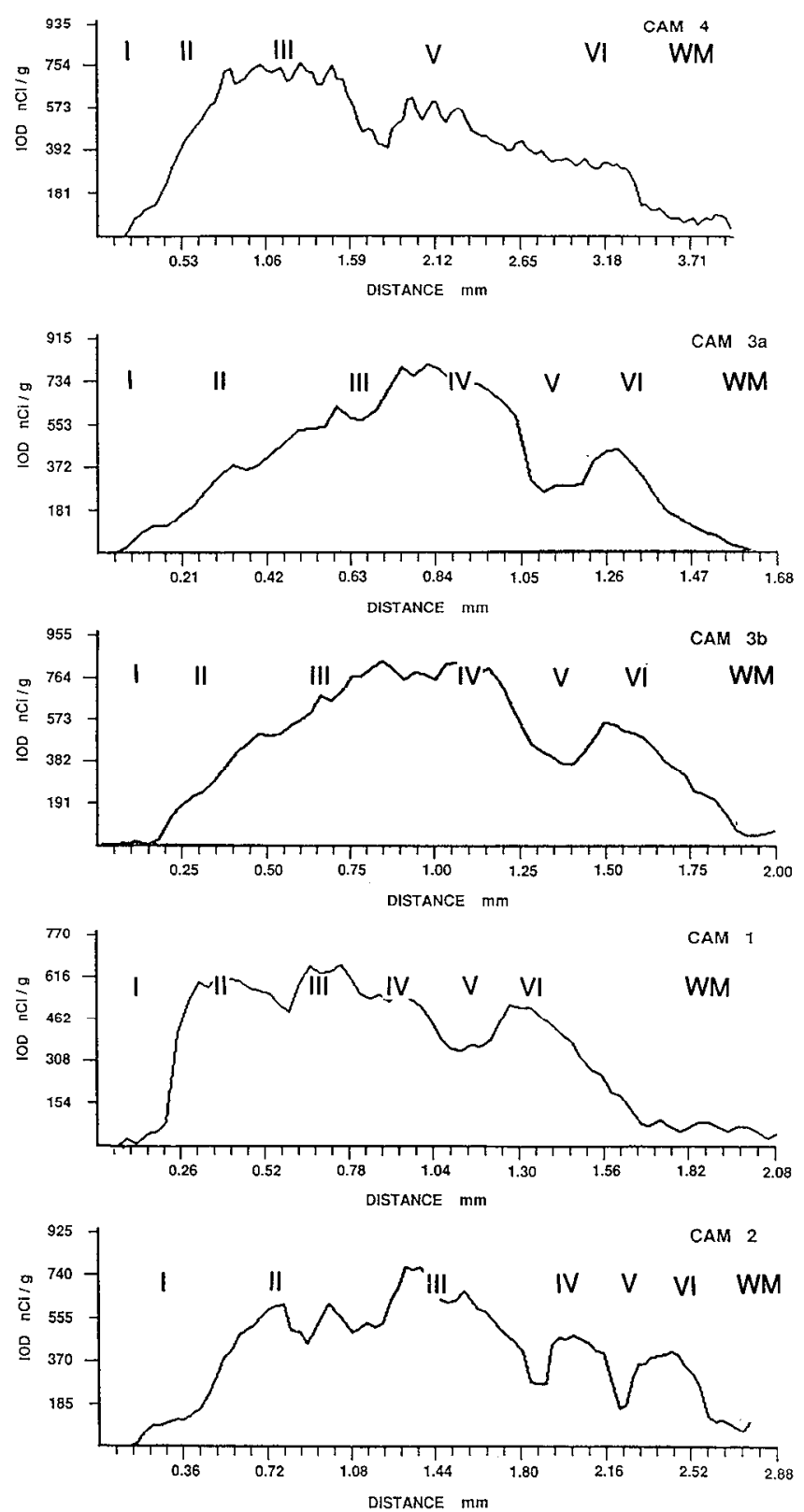
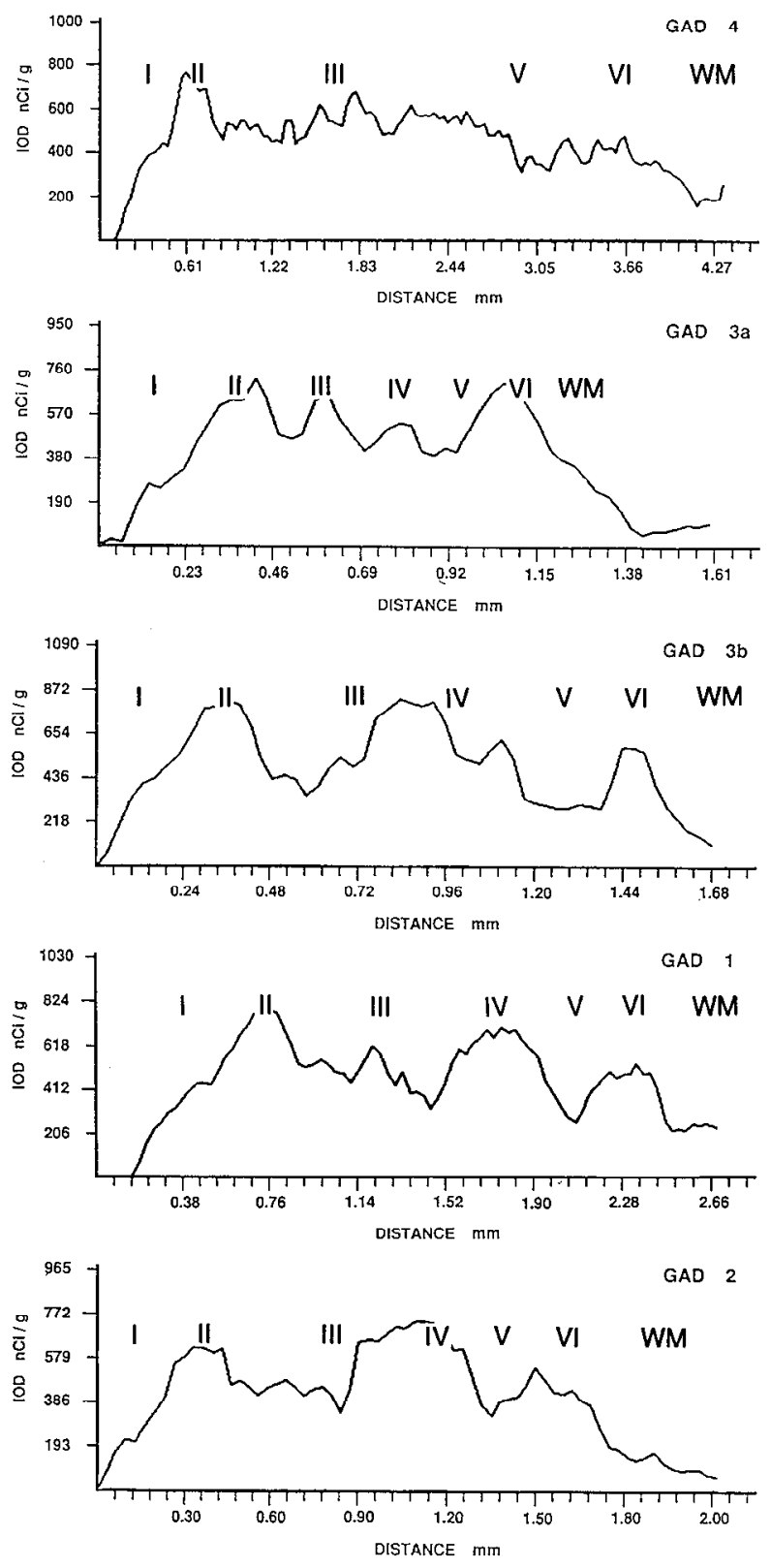

Figure 9. Graphs derived from optical density measurements taken across areas 4, 3a, 3b, 1, and 2 in regions indicated by arrows in Figure 8 and showing laminar concentrations of radioactivity. Note distinct laminar patterns of labeling with each riboprobe and lack of significant labeling with CAM II kinase- $\alpha$ riboprobe in layer I and the subcortical white matter.

Abramof, 1969, 1970). They are customarily thought to form the main route for the flow of excitation out of layer IV, at least in the visual cortex (Gilbert, 1983; Martin, 1984; Lund, 1990), and there is some evidence that they are immunoreactive for glutamate in the somatosensory and other areas (DeFelipe et a1., 1988; Kisvárday et al., 1989).

The dendritic spine-bearing cells of the cerebral cortex, that is, the pyramidal and the spiny nonpyramidal cells, are the major sources of excitatory synapses in the cerebral cortex and also receive by far the greatest number of asymmetric ("excitatory") synapses, most of them situated on the dendritic spine heads (Colonnier, 1968; Jones and Powell, 1969; Peters and Kaiserman-Abramof, 1969, 1970; Sloper et al., 1979; Shanks and Powell, 1981; Feldman, 1984; Freund et al., 1989). It is of interest, therefore, that CAM II kinase is capable both of in- ducing release of glutamate (Nichols et al., 1990) and of itself being activated by glutamate (Scholz and Palfrey, 1991; Fukunaga et al., 1992).

It is also of interest to reflect that because of its expression in particular neuronal populations, CAM II kinase- $\alpha$ protein will be differentially distributed at the synaptic level. At synapses Inlade by the axons of excitatory amino acid-producing neurons on other excitatory neurons, CAM II kinase- $\alpha$ will be found in both the presynaptic terminal and the postsynaptic membrane thickening. At similar excitatory synapses onto GABA cells, it will be present only presynaptically; at GABAergic synapses onto excitatory cells it will be present only postsynaptically although it may not be specifically associated with the symmetric postsynaptic thickenings of the GABA synapses; and at synapses between GABA cells, it will not be present either pre- or post- 

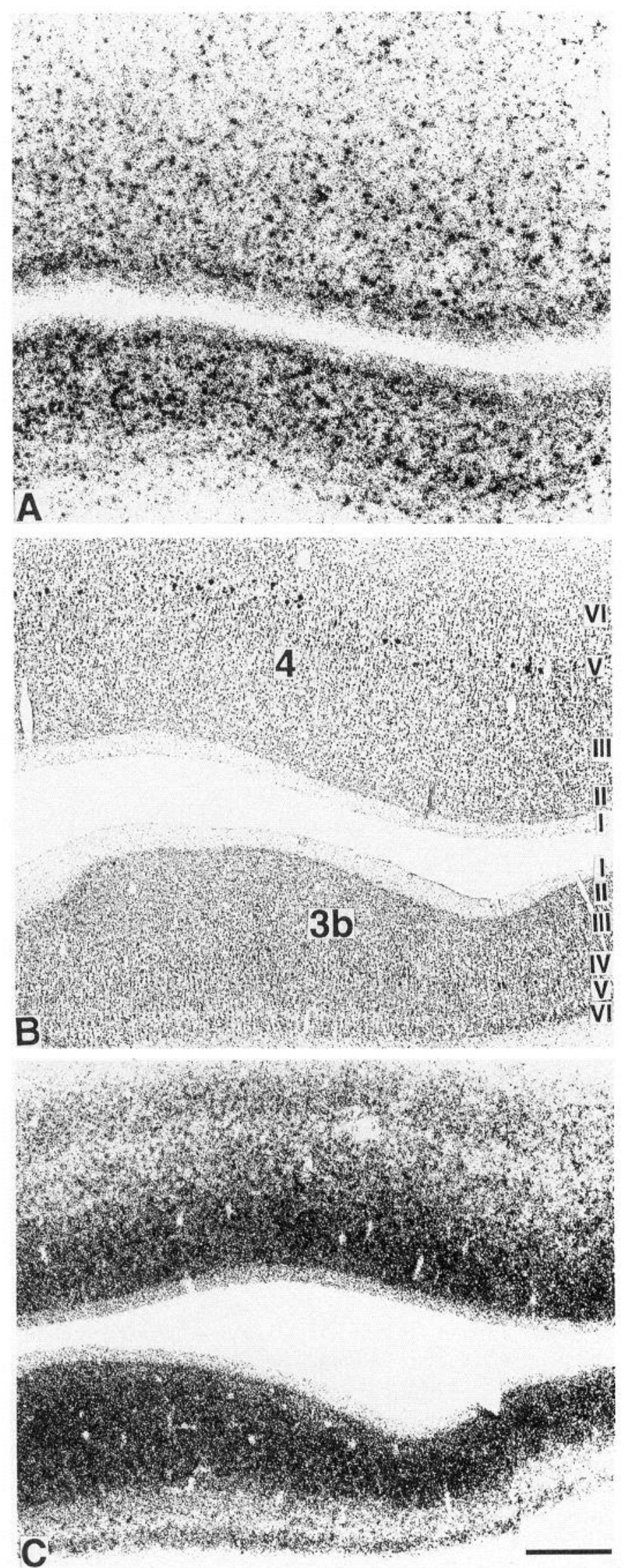

Figure 10. Photomicrographs of film autoradiograms showing adjacent parts of areas $3 \mathrm{~b}$ and 4 in sections cut along the line of the central synaptically. A further range of variations can be deduced from the apparent absence of the enzyme from a subpopulation of pyramidal neurons. Hence, although capable of phosphorylating many substrates (Fukunaga et al., 1982; Bennett et al., 1983; Yamauchi and Fujisawa, 1983; Kuret and Schulman, 1984; Schulman, 1984; Vulleit et al., 1984; Pearson et al., 1985; Mah et al., 1992), the enzyme may show more restricted actions, being denied access to certain substrates by the nature of its localization. It is interesting to note that CAM II kinase is capable of phosphorylating recombinant glutamate receptors and native glutamate receptors in nerve terminal and postsynaptic density preparations and that activated CAM II kinase significantly enhances kainate-induced ion currents in cultured hippocampal neurons (McGlade-McCulloch et al., 1993). CAM II kinase, however, appears to have no action on $\mathrm{GABA}_{\mathrm{A}}$ receptor subunit polypeptides, despite the capacity of many protein kinases to phosphorylate a number of these subunits, in some cases differentially (Sigel and Baur, 1988; Sweetnam et al., 1988; Kirkness et al., 1989; Browning et al., 1990). This would tend to support the notion of a lack of association of CAM II kinase with the postsynaptic as well as the presynaptic sides of GABA synapses.

The most overt manifestation of the function of CAM II kinase- $\alpha$ is in the induction of long-term potentiation at synapses between Schaffer collaterals and CA1 pyramidal cells in the rodent hippocampus (Malenka et al., 1989; Malinow et al., 1989; Ocorr and Schulman, 1991; Silva et al., 1992a). From previous studies of CAM II kinase- $\alpha$ gene expression in the hippocampus (Burgin et al., 1990; Benson et al., 1992a,b), the enzyme should be found on both the pre- and postsynaptic sides of the relevant synapse. It is, thus, not possible to deduce that the action of CAM II kinase- $\alpha$ in inducing long-term potentiation at this excitatory, glutamergic synapse is predominantly pre- or postsynaptic, and either or both are possible. In the sensory-motor cortex, because CAM II kinase- $\alpha$ is expressed in thalamic relay cells (Benson et al., 1991b), it should be found in the terminals of thalamocortical axons. It is probably these axons that are stained immunocytochemically for CAM II kinase- $\alpha$ in the white matter. The present study showing the presence of CAM II kinase- $\alpha$ in many pyramidal cells in layer III would imply that it is also present in the terminals of corticocortical and commissural axons that arise in large part from these cells (Jones et al., 1975, 1978, 1979). The three major groups of afferents to the sensory-motor areas are thus CAM II kinase- $\alpha$ positive. The terminations of these afferents on spiny neurons of layer IV and on pyramidal neurons in layers III-VI (Sloper and Powell, 1979; Shanks and Powell, 1981) imply the presence of the enzyme pre- and postsynaptically at the major synapses for the transfer of information in the sensory-motor areas. Long-term potentiation has been demonstrated in neurons of the cat motor area following tetanic stimulation of the somatic sensory areas (Iriki et al., 1989, 1991), and CAM II kinase injected into motor cortex (pyramidal) neurons can substantially affect input resistance (Woody et al., 1984). Hence, the enzyme may have an involvement in fundamental mecha-

sulcus. $A$, hybridized to the GAD riboprobe, and $C$, hybridized to the CAM II kinase- $\alpha$ riboprobe, show clearly the laminar concentrations of GAD and CAM II kinase- $\alpha$ mRNAs and the overlapping and to some extent complementary character of the laminar patterns of distribution. $C$ is stained with thionin. $B$ and $C$ are adjacent sections; $A$ is $350 \mu \mathrm{m}$ distant. Scale bar, $1 \mathrm{~mm}$. 

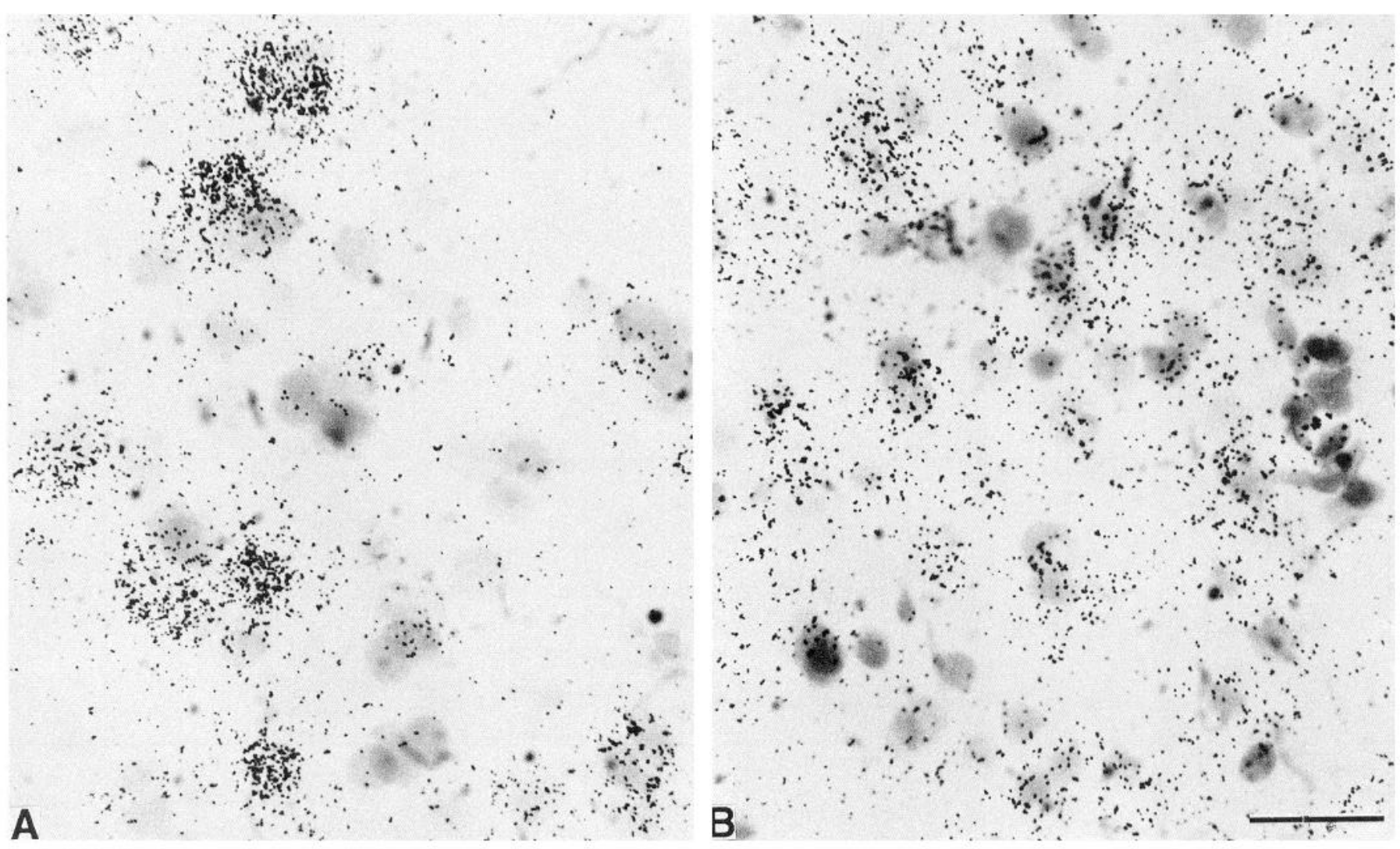

Figure 11. Bright-field photomicrographs from portions of layer III of area $3 \mathrm{~b}$, showing large and small grain clusters indicative of labeling of large and small GABA cell somata by the GAD riboprobe $(A)$, and more diffuse labeling of somata and neuropil by the CAM II kinase- $\alpha$ riboprobe $(B)$. Unlabeled, small dark profiles are nuclei of neuroglial cells. Scale bar, $25 \mu \mathrm{m}$.

nisms of cellular learning that extends in the cerebral cortex far wider than the hippocampus.

The counts of GABA cells made from immunocytochemical preparations in this study are in close agreement with those made previously (Hendry et al., 1987) and show that in all areas the cells amount to approximately $25-30 \%$ of the neuronal population. The counts made from preparations hybridized for GAD67 mRNA are approximately $5 \%$ higher. This may reflect the

\begin{tabular}{|c|c|c|c|c|c|c|c|}
\hline Area & GABA & GAD & CAMIIK & Nissl & $\%$ GABA & $\%$ GAD & \%CAMIIK \\
\hline \multicolumn{8}{|l|}{ M1 } \\
\hline 4 & $43.6 \pm 10.2$ & $49.6 \pm 16.3$ & $84.2 \pm 13.2$ & $161.2 \pm 27.7$ & $28.6 \pm 1.2$ & $31.4 \pm 10.5$ & $52.9 \pm 8.0$ \\
\hline $3 a$ & $32.2 \pm 5.7$ & $40.4 \pm 5.7$ & $54.4 \pm 9.1$ & $150.0 \pm 15.4$ & $21.7 \pm 4.0$ & $27.2 \pm 4.9$ & $36.9 \pm 8.4$ \\
\hline $3 b$ & $34.8 \pm 6.8$ & $43.4 \pm 8.9$ & $86.8 \pm 12.1$ & $158.6 \pm 9.8$ & $21.9 \pm 4.3$ & $27.6 \pm 6.6$ & $55.0 \pm 9.7$ \\
\hline 1 & $39.4 \pm 8.6$ & $44.6 \pm 5.2$ & $86.2 \pm 15.4$ & $151.6 \pm 18.4$ & $26.2 \pm 6.3$ & $29.5 \pm 2.8$ & $57.2 \pm 10.7$ \\
\hline 2 & $41.0 \pm 4.0$ & $43.0 \pm 5.1$ & $88.4 \pm 6.8$ & $150.6 \pm 23.8$ & $27.6 \pm 4.1$ & $28.7 \pm 2.3$ & $59.9 \pm 10.2$ \\
\hline \multicolumn{8}{|l|}{ M2 } \\
\hline 4 & $45.6 \pm 4.4$ & $51.2 \pm 7.4$ & $79.4 \pm 6.5$ & $167.2 \pm 17.9$ & $27.6 \pm 4.3$ & $30.5 \pm 10.5$ & $47.7 \pm 4.4$ \\
\hline $3 a$ & $31.4 \pm 3.8$ & $40.4 \pm 5.9$ & $60.8 \pm 8.8$ & $124.0 \pm 23.5$ & $25.9 \pm 5.4$ & $34.0 \pm 9.9$ & $50.0 \pm 9.3$ \\
\hline $3 b$ & $40.0 \pm 4.6$ & $45.0 \pm 8.1$ & $55.2 \pm 4.4$ & $150.4 \pm 14.5$ & $26.7 \pm 2.8$ & $30.6 \pm 9.1$ & $37.1 \pm 5.5$ \\
\hline 1 & $44.2 \pm 6.9$ & $44.4 \pm 6.8$ & $57.2 \pm 4.8$ & $170.4 \pm 13.1$ & $25.9 \pm 4.0$ & $26.2 \pm 4.5$ & $33.7 \pm 4.0$ \\
\hline 2 & $44.2 \pm 4.3$ & $43.8 \pm 5.5$ & $60.4 \pm 4.6$ & $153.2 \pm 18.4$ & $29.4 \pm 5.5$ & $28.9 \pm 4.8$ & $40.2 \pm 7.9$ \\
\hline \multicolumn{8}{|l|}{ M3 } \\
\hline 4 & $44.2 \pm 7.6$ & $47.6 \pm 7.5$ & $64.8 \pm 11.9$ & $156.8 \pm 13.8$ & $28.6 \pm 7.0$ & $30.6 \pm 5.9$ & $41.4 \pm 7.1$ \\
\hline $3 a$ & $30.6 \pm 4.2$ & $36.0 \pm 3.7$ & $62.4 \pm 9.3$ & $159.0 \pm 14.4$ & $19.4 \pm 3.1$ & $22.8 \pm 3.5$ & $39.1 \pm 2.8$ \\
\hline $3 b$ & $34.4 \pm 8.6$ & $41.6 \pm 9.9$ & $86.4 \pm 4.5$ & $161.8 \pm 11.8$ & $21.5 \pm 6.3$ & $25.8 \pm 6.4$ & $53.7 \pm 5.4$ \\
\hline 1 & $45.2 \pm 5.4$ & $45.4 \pm 6.2$ & $75.8 \pm 8.8$ & $162.2 \pm 8.7$ & $27.8 \pm 2.3$ & $28.0 \pm 3.9$ & $46.8 \pm 5.2$ \\
\hline 2 & $46.3 \pm 6.9$ & $42.6 \pm 7.6$ & $60.5 \pm 10.7$ & $160.3 \pm 17.6$ & $29.4 \pm 6.5$ & $27.7 \pm 2.6$ & $37.6 \pm 3.3$ \\
\hline
\end{tabular}




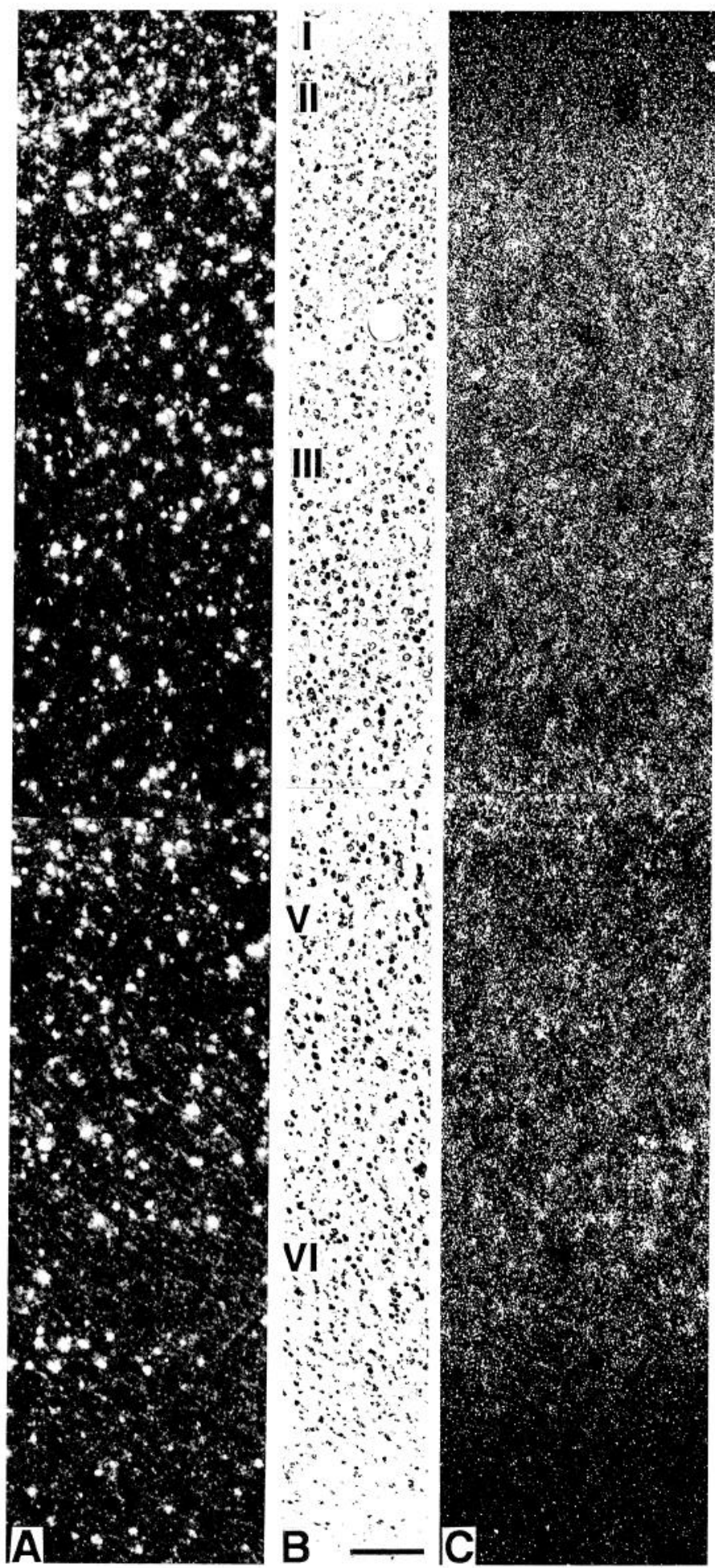

Figure 12. Dark-field photomicrographs from comparable regions of adjacent sections through area 4 , showing in situ hybridization of the GAD $(A)$ and CAM II kinase- $\alpha(C)$ riboprobes matched to a brightfield photomicrograph $(B)$, showing the thionin-stained lamination pattern. Individual labeled somata are clearly visible in $A$. Heavy neuropil labeling, characteristic of CAM II kinase- $\alpha$ mRNA localization, tends to obscure labeling of individual cells in $C$ (compare Figs. 8, 11, 12). Scale bar, $100 \mu \mathrm{m}$. greater sensitivity of the in situ hybridization method in labeling GABA cells, although the counting of aggregations of silver grains rather than actual cell somata in the cRNA hybridized sections may have predisposed to slightly higher counts. In any case, the counts of cells labeled for GAD-67 mRNA do not differ substantially from those made on immunocytochemical preparations. This suggests not only that GABA immunoreactivity gives an accurate estimate of the percentage of cortical GABA neurons but also that GAD-67 is expressed in all of them. A second form of GAD with a $65 \mathrm{kDa}$ molecular weight is encoded by a separate GAD gene in cats and humans (Wuenschell et al., 1986; Kobayashi et al., 1987; Kaufman et al., 1989; Erlander et al., 1991; Bu et al., 1992). All evidence, however, points to its being coexpressed with GAD-67 (Houser et al., 1989). There seems little reason to believe, therefore, that GAD67 and GAD-65 gene expression would label different populations of cortical GABA cells, although this needs to be confirmed.

CAM II kinase- $\alpha$ cells in the sensory-motor areas, as estimated from counts of immunocytochemical preparations only, account for approximately $50 \%$ of the neuronal population, with lower percentages in areas $3 \mathrm{a}$ and $3 \mathrm{~b}$. Together, therefore, GABA cells and CAM II kinase- $\alpha$ cells cannot account for the total population of cortical neurons. The small numbers of cortical neurons that can be identified by other markers, such as peptide immunoreactivity not colocalized with GABA (Hendry et al., $1984 a, b)$ or histochemical staining for nicotinamide-adeninedinucleotide diaphorase (NADPH-d) (Sandell, 1986; Kowall and Beal, 1988; Bredt et al., 1991), cannot account for the missing $20-25 \%$. The direct evidence from the immunofluorescent preparations, which show a lack of CAM II kinase- $\alpha$ immunoreactivity in pyramidal cells adjacent to those that are well stained, indicates that this missing percentage is made up of a population of non-CAM II kinase- $\alpha$ expressing pyramidal cells. The paucity of pyramidal cells immunoreactive for the enzyme in layer $\mathrm{V}$ of area $3 \mathrm{~b}$ in the immunoperoxidase preparations is in conformity with this. The lack of staining does not affect pyramidal cells in any particular layer since stained pyramidal cells are found in all layers. Therefore, the lack of CAM II kinase- $\alpha$ immunoreactivity does not appear confined to a single, laminabased population of pyramidal cells. Possibly the difference could be based on different targets of projection but this needs to be investigated by appropriate methods. Another potential distinction could be based upon the differential localization of glutamate or aspartate or some other acidic amino acid transmitter. Glutamate and aspartate immunoreactivity or immunoreactivity for related enzymes have been described in different pyramidal cells in the rat and monkey somatic sensory cortex (Donoghue et al., 1985; Conti et al., 1987). This, too, needs further investigation. It is unlikely that an absence of CAM II kinase $-\alpha$ will be replaced by expression of CAM II kinase- $\beta$, since these, at least in the hippocampus, are expressed in the same cell population (Burgin et al., 1990).

There was a mismatch of immunoreactivity for CAM II kinase- $\alpha$ and in sit $u$ hybridization for its mRNA in the subcortical white matter. Immunoreactive neurons were present in the white matter in considerable numbers but no hybridization could be detected. Although it is possible that CAM II kinase- $\alpha$ mRNA levels are so low in the white matter cells that they escape detection, other considerations may apply. The monoclonal antibody used appears to be highly specific for the $\alpha$ subunit protein (Erondu and Kennedy, 1985), so cross-reactivity with a related 

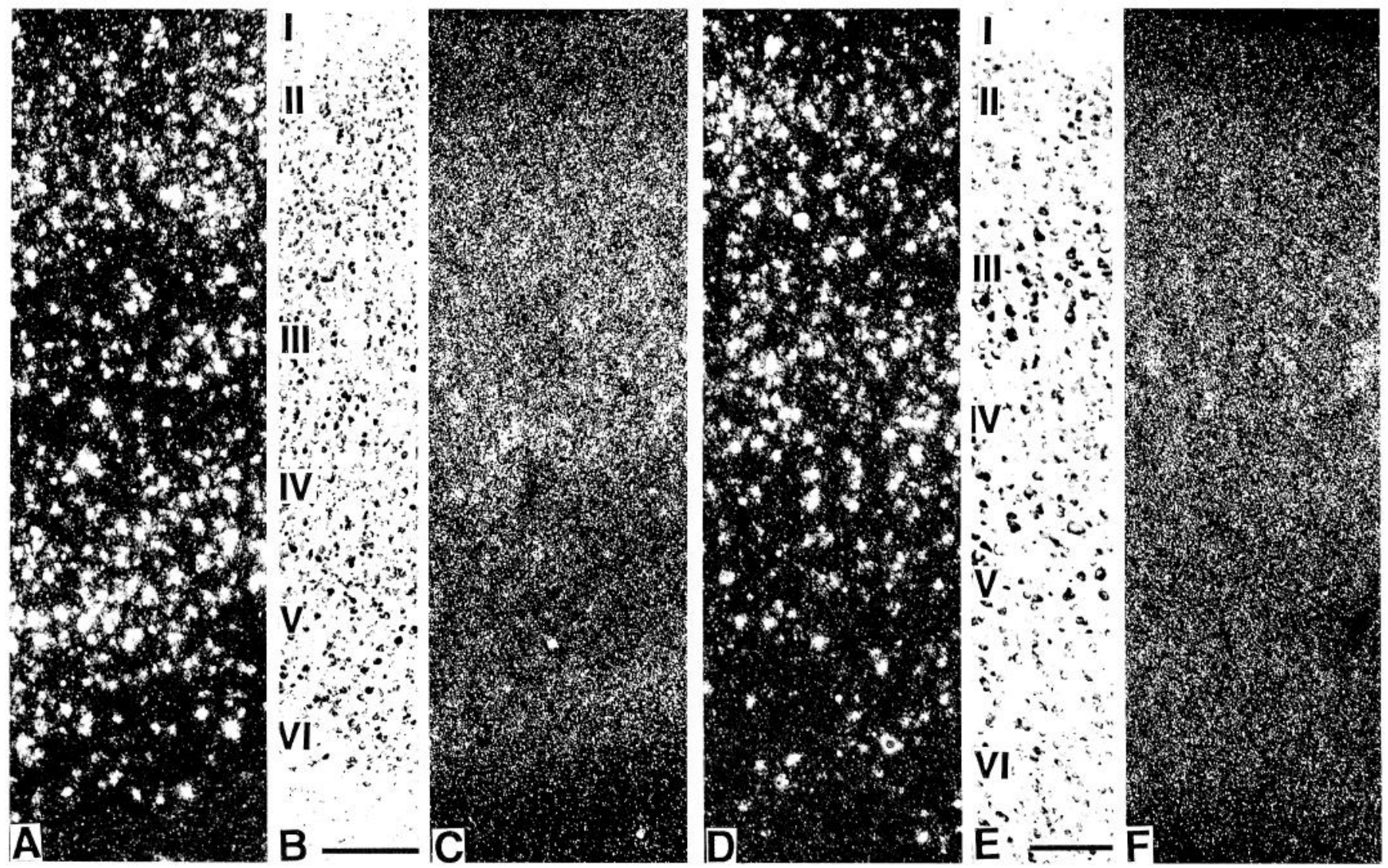

Figure 13. Dark-field photomicrographs from comparable regions of adjacent sections through areas $3 \mathrm{~b}(A, C)$ and 1 (D, F), showing in situ hybridization of $\operatorname{GAD}(A, D)$ and CAM II kinase- $\alpha$ riboprobes, matched to bright-field photomicrographs $(B, E)$ of the thionin-stained lamination pattern. Laminar concentrations of labeling are clearly evident. Scale bars, $100 \mu \mathrm{m}$.

protein seems unlikely. The cRNA probes used to localize CAM II kinase- $\alpha$ mRNA are derived from monkey cDNAs that contain sequences that are highly conserved between rat and monkey (Benson et al., 1991a), and the probes should recognize mRNAs coding for the same $\alpha$ protein as that of the rat against which the monoclonal antibody was made. The monkey cDNA also contains, however, a 33 base pair insert that does not appear in the published rat sequence. This does not affect the capacity of the derived cRNA probes to hybridize to CAM II kinase- $\alpha$ mRNA (Benson et al., 1991a), including in the rat (Benson et al., 1992a,b). Therefore, if cross-reactivity of the antibody with CAM II kinase $-\beta$ or some other CAM II kinase subunit protein can be ruled out, a possibility exists that some alternatively spliced or edited form of CAM II kinase- $\alpha$ mRNA is present in the white matter cells and is not detected by the riboprobes.

A distinctive feature of in situ hybridization for CAM II kinase- $\alpha$ that has been remarked upon in previous studies on diverse regions of the rat and monkey brain (Burgin et al., 1990; Benson et al., 1991a,b, 1992a,b) is the high level of neuropil hybridization. This has been shown to reflect the high levels of CAM II kinase- $\alpha$ mRNA in the dendrites of expressing cells (Burgin et al., 1990; Benson et al., 1992b). It contrasts with the pattern of hybridization seen with probes for other neuronal mRNAs, for example, GAD, which almost invariably outlines cell somata only. In the hippocampus, at least, it also contrasts with the pattern of hybridization for CAM II kinase- $\beta$, which is largely restricted to the somata of pyramidal cells (Burgin et al., 1990). It is likely that the intense dendritic concentration of
CAM II kinase- $\alpha$ mRNA in cortical pyramidal cells reflects the association of the $\alpha$ subunit with the postsynaptic densities of the large numbers of asymmetrical synapses that are found on these cells (Colonnier, 1968; Peters and Kaiserman-Abramof, 1969, 1970; Jones and Powell, 1969). The $\alpha$ subunit protein displays a higher affinity for the postsynaptic density than the $\beta$ subunit (Miller and Kennedy, 1985). Asymmetric synapses are predominantly located on the dendritic spines (Colonnier, 1968; Jones and Powell, 1969; Peters and Kaiserman-Abramof, 1970), at the necks of which small aggregations of polyribosomes and/or rough endoplasmic reticulum are commonly found (Steward and Levy, 1982; Steward, 1983). Given the apparent involvement of CAM II kinase- $\alpha$ in mechanisms of long-term plasticity at comparable spine synapses in hippocampal pyramidal cells (Silva et al., 1992a), and the rapid changes wrought in CAM II kinase- $\alpha$ mRNA and protein levels in the cerebral cortex under activity-dependent conditions (Hendry and Kennedy, 1986; Benson et al., 1991a; Bronstein et al., 1992), one may conjecture that the mRNA is located in the immediate vicinity of sites at which rapid synaptic changes demand immediate translation of the message and production of the protein. Such requirements could involve the amount of enzyme available at the postsynaptic membrane density where storage may demand the turnover of individual $\alpha$ subunits rather than the holoenzyme (Lisman and Goldring, 1988; Siekevitz, 1991). The rapidity with which representational maps can be induced to change under activity-dependent conditions in the sensorymotor cortex (e.g., Merzenich et al., 1983a,b; Wall et al., 1986; 
Clark et al., 1988; Donoghue and Sanes, 1988; Donoghue et al., 1990; Jenkins et al., 1990; Garraghty and Kaas, 1991; Jacobs and Donoghue, 1991; Pons et al., 1991) suggests that the phenomenon may be based on rapidly inducible changes in synaptic strength that cause previously silent or less effective excitatory synapses to become more effective. It is possible that activityinduced production of CAM II kinase close to the synapses plays a role in this. Increased production of the enzyme may also be demanded for phosphorylating structural proteins involved in synaptic and spine remodeling that are thought to be concomitants of longer-term plastic changes in central neurons (reviewed in Wallace et al., 1991; Lisman and Harris, 1993).

\section{References}

Beaman-Hall CM, Hozza MJ, Vallano ML (1992) Detection of mRNAs encoding distinct isoenzymes of type II calcium/calmodulin-dependent protein kinase using the polymerase chain reaction. J Neurochem 58:1259-1267.

Benferati F, Neyroz P, Bähler M, Masotti L, Greengard P (1990) Timeresolved fluorescence study of the neuron-specific phosphoprotein synapsin I: evidence for phosphorylation-dependent conformational changes. J Biol Chem 265:12584-12595.

Benferati F, Valtorta F, Rubenstein JL, Gorelock FS, Greengard P, Czernik AJ (1992) Synaptic vesicle-associated $\mathrm{Ca}^{2+} /$ calmodulindependent protein kinase II is a binding protein for synapsin I. Naturc $359: 417-419$.

Bennett MK, Kennedy MB (1987) Deduced primary structure of the $\beta$ subunit of brain type II Ca ${ }^{2+} /$ calmodulin-dependent protein kinase determined by molecular cloning. Proc Natl Acad Sci USA 84:17941798.

Bennett MK, Erondu NE, Kennedy MB (1983) Purification and characterization of a calmodulin-dependent protein kinase that is highly concentrated in brain. J Biol Chem 258:12735-12744.

Benson DL, Isackson PJ, Gall CM, Jones EG (1991a) Differential effects of monocular deprivation on glutamic acid decarboxylase and type II calcium-calmodulin-dependent protein kinase gene expression in the adult monkey visual cortex. J Neurosci 11:31-47.

Benson DL, Isackson PJ, Hendry SHC, Jones EG (1991b) Differential gene expression for glutamic acid decarboxylase and type II calciumcalmodulin-dependent protein kinase in basal ganglia, thalamus and hypothalamus of the monkey. J Neurosci 11:1540-1564.

Benson DL, Isackson PJ, Gall CM, Jones EG (1992a) Contrasting patterns in the localization of glutamic acid decarboxylase and $\mathrm{Ca}^{2+}$ calmodulin protein kinase gene expression in the rat central nervous system. Neuroscience 46:825-850.

Benson DL, Isackson PJ, Gall CM (1992b) Dendritic localization of type II calcium calmodulin-dependent protein kinase mRNA in normal and reinnervated rat hippocampus. Neuroscience 46:851-858.

Bezamohouta C, Zanetta JP, Revel MO, Zwiller J, Meyer A, Malviya AN, Vincendon G (1987) Nature and immunochemical characteristics of a Ca ${ }^{2+} /$ calmodulin kinase activity endowed in a highly insoluble protein purified from adult rat brain. J Neurochem 49:584592.

Bliss TVP, Collingridge GC (1993) A synaptic model of memory: longterm potentiation in the hippocampus. Nature 361:31-39.

Bredt DS, Glatt CE, Hwang PM, Fotuhi M, Dawson TM, Snyder SH (1991) Nitric oxide synthase protein and mRNA are discretely localized in neuronal populations of the mammalian CNS together with NADPH diaphorase. Neuron 7:615-624.

Bronstein JM, Farber DB, Wasterlain CG (1988) A retinal calmodulindependent kinase: calcium/calmodulin-stimulated and -inhibited states. J Neurochem 50:1438-1446.

Bronstein JM, Micevych P, Popper P, Huez G, Farber DB, Wasterlain CG (1992) Long-lasting decreases of type II calmodulin kinase expression in kindled rat brains. Brain Res 584:257-260.

Browning MD, Huganir R, Greengard P (1985) Protein phosphorylation and neuronal function. $J$ Neurochem 45:11-23.

Browning MD, Bureau M, Dudek EM, Olsen RW (1990) Protein kinase $\mathrm{C}$ and cAMP-dependent protein kinase phosphorylate the $\beta$ subunit of the purified $\gamma$-aminobutyric acid A receptor. Proc Natl Acad Sci USA 87:1315-1318.
Bu D-F, Erlander MG, Hitz BC, Tillakaratne NJK, Kaufnan DL, Wagner J, McPherson CB, Evans GA, Tobin AJ (1992) Two human glutamate decarboxylases, 65-kD GAD and 67-kD GAD, are each encoded by a single gene. Proc Natl Acad Sci USA 89:2115-2119.

Bulleit RF, Bennett MK, Malloy SS, Hurley JB, Kennedy MB (1988) Conserved and variable regions in the subunits of brain type II $\mathrm{Ca}^{2+}$ calmodulin-dependent protein kinase. Neuron 1:63-72.

Burgin KE, Waxham MN, Rickling S, Westgate SA, Mobley WC, Kelly PT (1990) In situ hybridization histochemistry of $\mathrm{Ca}^{2+} / \mathrm{calmodulin}-$ dependent protein kinase in developing rat brain. J Neurosci 10:17881798.

Canzek V, Wolfensberger M, Amsler U, Cuénod M (1981) In vivo release of glutamate and aspartate following optic nerve stimulation. Nature 293:572-574.

Clark SA, Allard T, Jenkins WM, Merzenich MM (1988) Receptive fields in the body-surface map in adult cortex defined by temporally correlated inputs. Nature 332:444-445.

Colbran RJ, Schworer CM, Hashimoto Y, Fong Y-L, Rich DP, Smith MK, Soderling TR (1989a) Calcium/calmodulin-dependent protein kinase II. J Biochem 258:313-325.

Colbran RJ, Smith MK, Schworer CM, Fong Y-L, Soderling TR (1989b) Regulatory domain of calcium/calmodulin-dependent protein kinase II. J Biol Chem 264:4800-4804.

Colonnier M (1968) Synaptic patterns on different cell types in the different laminae of the cat visual cortex, an electron microscope study. Brain Res 9:268-287.

Conti F, Rustioni A, Petrusz P, Towle AC (1987) Glutamate-positive neurons in the somatic sensory cortex of rats and monkeys. J Neurosci 7:1887-1901.

DeFelipe J, Conti F, Van Eyck SL, Manzoni T (1988) Demonstration of glutamate positive axon terminals forming asymmetric synapses in cat neocortex. Brain Res 455:162-165.

Donoghue JP, Sanes JN (1988) Organization of adult motor cortex representation patterns following neonatal forelimb nerve injury in rats. J Neurosci 8:3221-3232.

Donoghue JP, Wenthold RJ, Altschuler RA (1985) Localization of glutaminase-like and aspartate aminotransferase-like immunoreactivity in neurons of cerebral neocortex. J Neurosci 5:2597-2608.

Donoghue JP, Suner S, Sanes JN (1990) Dynamic organization of primary motor cortex output in target muscles in adult rats. II. Rapid reorganization following motor nerve lesions. Exp Brain Res 79:492503.

Erlander MG, Tillakaratne NJK, Feldblum S, Patel N, Tobin AJ (1991) Two genes encode distinct glutamate decarboxylases. Neuron 7:91100.

Erondu NE, Kennedy MB (1985) Regional distribution of type II Ca ${ }^{2+}$ calmodulin dependent protein kinase in rat brain. J Neurosci 5:32703277.

Feldman M (1984) Morphology of the neocortical pyramidal neuron. In: Cerebral cortex, Vol 1, Cellular components of the cerebral cortex (Peters A, Jones EG, eds), pp 123-200. New York: Plenum.

Fonnum F (1984) Glutamate: a neurotransmitter in the mammalian brain. J Neurochem 42:1-11.

Freund TF, Martin KAC, Soltesz I, Somogyi P, Whitteridge DI (1989) Arborization pattern and postsynaptic targets of physiologically identified thalamocortical afferents in striate cortex of the macaque monkey. J Comp Neurol 289:315-336.

Fukunaga K, Yamato H, Matsui K, Higashi K, Miyamoto E (1982) Phosphorylation and activation of calmodulin-sensitive cyclic nucleolide phosphodiesterase by a brain $\mathrm{Ca}^{2+}$, calmodulin-dependent protein kinase. Life Sci 35:493-499.

Fukunaga K, Goto S, Miyamoto E (1988) Immunohistochemical localization of $\mathrm{Ca}^{2+} /$ calmodulin-dependent protein kinase II in rat brain and various tissues. J Neurochem 51:1070-1078.

Fukunaga K, Soderling TR, Miyamoto E (1992) Activation of $\mathrm{Ca}^{2+}$ calmodulin dependent protein kinase II and protein kinase $\mathrm{C}$ by glutamate in cultured rat hippocampal neurons. J Biol Chem 267:2252722533

Garraghty PE, Kaas JH (1991) Large-scale functional reorganization in adult monkey cortex after peripheral nerve injury. Proc Natl Acad Sci USA 88:6976-6980.

Gilbert CD (1983) Microcircuitry of the visual cortex. Annu Rev Neurosci 6:217-247.

Goldenring JR, Gonzales B, McGuire JS Jr, DeLorenzo RJ (1983) Purification and characterization of a calmodulin-dependent kinase 
from rat brain cytosol able to phosphorylate tubulin and microtubule associated proteins. J Biol Chem 258:12632-12640.

Goldenring JR, McGuire JS, DeLorenzo RJ (1984) Identification of the major postsynaptic density protein as homologous with the major calmodulin-binding subunit of a calmodulin-dependent protein kinase. J Neurochem 42:1077-1084.

Greengard P, Valtorta F, Czernik AJ, Benfenati F (1993) Synaptic vesicle phosphoproteins and regulation of synaptic function. Science 259:780-785.

Hackett JT, Stephen L, Cochran SL, Greenfield LJ, Brosius DC, Veda $T$ (1990) Synapsin I injected presynaptically into goldfish Mauthner axons reduces quantal synaptic transmission. J Neurophysiol 63:701706.

Hanley RM, Means AR, Ono T, Kemp BE, Burgin KE, Waxman N, Kelly PT (1987) Functional analysis of a complementary DNA for the 50-kilodalton subunit of calmodulin kinase II. Science 237:293297.

Hanson PI, Schulman H (1992a) Inhibitory autophosphorylation of multifunctional $\mathrm{Ca}^{2+} /$ calmodulin-dependent protein kinase analyzed by site-directed mutagenesis. J Biol Chem 267:17216-17224.

Hanson PI, Schulman H (1992b) Neuronal $\mathrm{Ca}^{2+} /$ calmodulin-dependent protein kinases. Annu Rev Biochem 61:559-601.

Hendry SHC, Kennedy MB (1986) Immunoreactivity for a calmodulin-dependent protein kinase is selectively increased in macaque striate cortex after monocular deprivation. Proc Natl Acad Sci USA 83: $1536-1540$

Hendry SHC, Jones EG, DeFelipe J, Schmechel D, Brandon C, Emson PC (1984a) Neuropeptide-containing neurons of the cerebral cortex are also GABAergic. Proc Natl Acad Sci USA 81:6526-6530.

Hendry SHC, Jones EG, Emson PC (1984b) Morphology, distribution, and synaptic relations of somatostatin- and neuropeptide Y-immunoreactive neurons in rat and monkey neocortex. J Neurosci 4:24972517.

Hendry SHC, Schwark HD, Jones EG, Yan J (1987) Numbers and proportions of GABA immunoreactive neurons in different areas of monkey cerebral cortex. J Neurosci 7:1503-1519.

Houser CR, Hendry SHC, Jones EG, Vaughn JE (1983) Morphological diversity of GABA neurons demonstrated immunocytochemically in monkey sensory-motor cortex. J Neurocytol 12:617-638.

Houser CR, Vaughn JE, Hendry SHC, Jones EG, Peters A (1984) GABA neurons in the cerebral cortex. In: Cerebral cortex, Vol 2, Functional properties of cortical cells (Jones EG, Peters A, eds), pp 63-90. New York: Plenum.

Houser CR, Miyashiro JE, Kaufman DL, Tobin AJ (1989) Immunocytochemical studies using a new antiserum against bacterially produced feline glutamate decarboxylase. Soc Neurosci Abstr 15:488.

Ikeda A, Okuno S, Fujisawa H (1991) Studies on the generation of $\mathrm{Ca}^{2+} /$ calmodulin dependent activity of calmodulin-dependent protein kinase II by autophosphorylation. J Biol Chem 266:1 1582-11588.

Iriki A, Pavlides C, Keller A, Asanuma H (1989) Long-term potentiation in the motor cortex. Science 245:1385-1387.

Iriki A, Pavlides C, Keller A, Asanuma H (1991) Long-term potentiation of thalamic input to the motor cortex induced by coactivation of thalamocortical and corticocortical afferents. J Neurophysiol 65 : 1435-1441.

Jacobs KM, Donoghue JP (1991) Reshaping the cortical motor map by unmasking latent intracortical connections. Science 251:944-945.

Jenkins WM, Merzenich MM, Ochs MT, Allard T, Guic-Robles E (1990) Functional reorganization of primary somatosensory cortex in adult owl monkeys after behaviorally controlled tactile stimulation. J Neurophysiol 63:82-104.

Jones EG, Powell TPS (1969) Morphological variations in the dendritic spines of the neocortex. J Cell Sci 5:509-529.

Jones EG, Burton H, Porter R (1975) Commissural and cortico-cortical "columns" in the somatic sensory cortex of primates. Science 190:572-574.

Jones EG, Coulter JD, Hendry SHC (1978) Intracortical connectivity of architectonic fields in the somatic sensory, motor and parietal cortex of monkeys. J Comp Neurol 181:291-348.

Jones EG, Coulter JD, Wise SP (1979) Commissural columns in the sensory-motor cortex of monkeys. J Comp Neurol 188:113 136

Jones EG, DeFelipe J, Hendry SHC, Maggio JE (1988) A study of tachykinin immunoreactive neurons in monkey cerebral cortex. J Neurosci 8:1206-1224.

Jones EG, Hendry SHC, DeFelipe J, Benson DL (1993) GABA neu- rons and their role in activity-dependent plasticity of adult primate visual cortex. In: Cerebral cortex, Vol X, Primate visual cortex (Rockland KA, Peters A, Jones EG, eds), in press. New York: Plenum.

Kanaseki T, Ikeuchi Y, Sugiura LY, Yamauchi T (1991) Structural features of $\mathrm{Ca}^{2+} /$ calmodulin-dependent protein kinase II revealed by electron microscopy. J Cell Biol 115:1049-1060.

Kaufman DL, Houser CR, Tobin AJ (1989) Two forms of glutamate decarboxylase (GAD), with different $\mathrm{N}$-terminal sequences, have distinct intraneuronal distributions. Soc Neurosci Abstr 15:487.

Kelly PT, McGuinness TL, Greengard P (1984) Evidence that the major postsynaptic density protein is a component of a $\mathrm{Ca}^{2+} / \mathrm{cal}$ modulin dependent protein kinase. Proc Natl Acad Sci USA 81:945949.

Kennedy MB (1983) Experimental approaches to understanding the rolc of protcin phosphorylation in the regulation of neuronal function. Annu Rev Neurosci 6:493-525.

Kennedy MB, Bennett MK, Erondu NE (1983a) Biochemical and immunochemical evidence that the "major postsynaptic density protein" is a subunit of a calmodulin-dependent protein kinase. Proc Natl Acad Sci USA 80:7357-7361.

Kennedy MB, McGuinness T, Greengard P (1983b) A calcium/calmodulin dependent kinase from mammalian brain that phosphorylates synapsin I: partial purification and characterization. J Neurosci $3: 818-831$

Kim JS, Hassler R, Haug P, Paik KS (1977) Effect of frontal cortex ablation on striatal glutamic acid level in rat. Brain Res 132:370374.

Kirkness EF, Bovenkirk CF, Ueda T, Turner AJ (1989) Phosphorylation of $\gamma$-aminobutyrate $(\mathrm{G} \wedge \mathrm{BA})$ /benzodiazepine receptors by cyclic AMP-dependent protein kinase. Biochem J 259:613-616.

Kisvárday ZF, Cowey A, Somogyi P (1986) Synaptic relationships of a type of GABA-immunoreactive neuron (clutch cell), spiny stellate cells and lateral geniculate nucleus afferents in layer IVC of the monkey striate cortex. Neuroscience 19:714-761.

Kisvárday ZF, Cowey A, Smith DA, Somogyi P (1989) Interlaminar and lateral excitatory amino acid connections in the striate cortex of monkey. J Neurosci 9:667-682.

Kobayashi Y, Kaufman DL, Tobin AJ (1987) Glutamic acid decarboxylase cDNA: nucleotide sequence encoding an enzymatically active fusion protein. J Neurosci 7:2769-2772.

Kowall NW, Beal MF (1988) Cortical somatostatin, neuropeptide $Y$, and NADPH diaphorase neurons: normal anatomy and alterations in Alzhcimer's disease. Ann Neurol 23:105-144.

Kuret J, Schulman H (1984) Purification and characterization of a $\mathrm{Ca}^{2+} /$ calmodulin dependent protein kinase from rat brain. Biochemistry 23:5495-5504.

LeVay S (1973) Synaptic patterns in their visual cortex of the cat and monkey: electron microscopy of Golgi preparations. J Comp Neurol 150:53-86.

Lin CR, Kapiloff MS, Durgerain S, Tatemoto K, Russo AF, Hanson P, Schulman H, Rosenfeld MG (1987) Molecular cloning of a brainspecific calcium/calmodulin-dependent protein kinase. Proc Natl Acad Sci USA 84:5962-5966.

Lin J-W, Sugimure M, Llinás RR, McGuinness T, Greengard P (1990) Effects of synapsin I and calcium/calmodulin-dependent protein kinase II on spontaneous neurotransmitter release in the squid giant synapse. Proc Natl Acad Sci USA 87:8257-8261.

Lisman JE, Goldring MA (1988) Feasibility of long-term storage of graded information by the $\mathrm{Ca}^{2+} /$ calmodulin-dependent protein kinase molecules of the postsynaptic density. Proc Natl Acad Sci USA 85 : $5320-5324$.

Lisman J, Harris KM (1993) Quantal analysis and synaptic anatomyintegrating two views of hippocampal plasticity. Trends Neurosci 16 141-147.

Llinás R, McGuinness T, Leonard CS, Sugimori M, Greengard P (1985) Intraterminal injection of synapsin I or calcium/calmodulin dependent protein kinase II alters neurotransmitter release at the squid giant synapse. Proc Natl Acad Sci USA 82:3035-3039.

Llinás R, Gruner JA, Sugimori M, McGuinness T, Greengard P (1991) Regulation by synapsin I and $\mathrm{Ca}^{2+} /$ calmodulin-dependent protein kinase of transmitter release in squid giant synapse. J Physiol (Lond) 436:257-282.

Lou LL, Lloyd SJ, Schulman H (1986) Activation of the multifunctional $\mathrm{Ca}^{2+} /$ calmodulin-dependent protein kinase by autophosphor- 
ylation: ATP modulates production of an autonomous enzyme. Proc Natl Acad Sci USA 83:9497-9501.

Lund JS (1984) Spiny stellate neurons. In: Cerebral cortex, Vol 1, Cellular components of the cerebral cortex (Peters A, Jones EG, eds), pp 255-308. New York: Plenum.

Lund JS (1990) Excitatory and inhibitory circuiting and laminar mapping strategies in the primary visual cortex of the monkey. In: Signal and sense. Local and global order in perceptual maps (Edelman GM, Gall WF, Cowan WM, eds), pp 51-82. New York: Wiley-Liss.

Lund-Karlson R, Fonnum F (1978) Evidence for glutamate as a neurotransmitter in the corticifugal fibers to the dorsal lateral geniculate body and the superior colliculus in rats. Brain Res 151:457-467.

Mah VH, Eskin TA, Kazee AM, Lapham L, Higgins GA (1992) In situ hybridization of calcium/calmodulin dependent protein kinase II and tau mRNAs: species differences and relative preservation in Alzheimer's disease. Mol Brain Res 12:85-94.

Malenka RC, Kauer JA, Perkel DJ, Mauk MD, Kelly PT, Nicoll RA, Waxham MN (1989) An essential role for postsynaptic calmodulin and protein kinase activity in long-term potentiation. Nature 340 : 554-557.

Malinow R, Schulman H, Tsien RW (1989) Inhibition of postsynaptic PKC or CaMKII blocks induction but not expression of LTP. Science 245:862-866.

Martin KAC (1984) Neuronal circuits in cat striate cortex. In: Cerebral cortex, Vol II, Functional properties of cortical cells (Jones EG, Peters A, eds), pp 241-284. New York: Plenum.

Matute C, Streit P (1986) Monoclonal antibodies demonstrating GABAlike immunoreactivity. Histochemistry 56:147-157.

McGeer EG, McGeer PL, Singh K (1978) Kainate-induced degeneration of neostriatal neurons: dependency upon cortico-striatal tract. Brain Res 139:381-383.

McGlade-McCulloch E, Y amamoto H, Tan S-E, Brickey DA, Soderling TR (1993) Phosphorylation and regulation of glutamate receptors by calcium/calmodulin-dependent protein kinase II. Nature 362:640642.

McGuinness TL, Lai Y, Greengard P, Woodgett JR, Cohen P (1983) A multifunctional calmodulin-dependent protein kinase. Similarities between skeletal muscle glycogen synthase kinase and a brain synapsin I kinase. FEBS Lett 163:329-334.

McGuinness TL, Lai Y, Greengard P (1985) $\mathrm{Ca}^{2+} /$ calmodulin-dependent protein kinase II. Isozymic forms from rat forebrain and cerebellum. J Biol Chem 260:1696-1704.

McGuinness TL, Brady ST, Gruner JA, Sugimori M, Llinás R, Greengard P (1989) Phosphorylation-dependent inhibition by synapsin I of organelle movement in squid axoplasm. J Neurosci 9:4138-4149.

McGuire BA, Gilbert CD, Rivlin PK, Wiesel IN (1991) Targets of horizontal connections in macaque primary visual cortex. J Comp Neurol 305:370-392.

Merzenich MM, Kaas JH, Wall J, Nelson RJ, Sur M, Felleman D (1983a) Topographic reorganization of somatosensory cortical areas $3 \mathrm{~b}$ and 1 in adult monkeys following restricted deafferentation. Neuroscience $8: 33-56$.

Merzenich MM, Kaas JH, Wall J, Sur M, Nelson RJ, Fellman D (1983b) Progression of change following median nerve section in the cortical representation of the hand in areas $3 \mathrm{~b}$ and 1 in adult owl and squirrel monkeys. Neuroscience 10:639-666.

Miller SG, Kennedy MB (1985) Distinct forebrain and cerebellar isozymes of type II $\mathrm{Ca}^{2+} /$ calmodulin-dependent protein kinase associate differently with the post-synaptic density fraction. J Biol Chem 260: 9039-9046.

Nairn AC, Hemmings HC Jr, Greengard P (1985) Protein kinases in the brain. Annu Rev Biochem 54:931-976.

Nestler EJ, Greengard P (1984) Protein phosphorylation in the nervous system. New York: Wiley.

Nichols RA, Sihra TS, Czernik AJ, Nair AC, Greengard P (1990) Calcium/calmodulin-dependent protein kinase II increases glutamate and noradrenaline release from synaptosomes. Nature 343:647-651.

Nichols RA, Chilicote TJ, Czernik AJ, Greengard P (1992) Synapsin I regulates glutamate release from rat brain synaptosomes. J Neurochem 58:783-785.

Ocorr KA, Schulman $\mathrm{H}$ (1991) Activation of multifunctional $\mathrm{Ca}^{2+}$ calmodulin dependent kinase in intact hippocampal slices. Neuron 6:907-914.

Ottersen OP, Storm-Mathisen J (1984) Neurons containing or accumulating transmitter amino acids. In: Handbook of chemical neu- roanatomy, Vol 3, Classical transmitters and transmitter receptors in the CNS, Pt II (Björklund A, Hökfelt T, Kuhar MJ, eds), pp 141246. Amsterdam: Elsevier.

Ouimet CC, McGuinness T, Greengard P (1984) Immunocytochemical localization of calcium/calmodulin-dependent protein kinase II in rat brain. Proc Natl Acad Sci USA 81:5604-5608.

Pearson RB, Woodgett JR, Cohen P, Kemp BE (1985) Substrate specificity of a multifunctional calmodulin-dependent protein kinase. $\mathrm{J}$ Biol Chem 260:14471-14476.

Peters A, Kaiserman-Abramof IR (1969) The small pyramidal neuron of the rat cerebral cortex: the synapses upon dendritic spines. Z Zellforsch Mikrosk Anat 100:487-506.

Peters A, Kaiserman-Abramof IR (1970) The small pyramidal neuron of the rat cerebral cortex: the perikaryon, dendrites and spines. Am J Anat 127:321-356.

Pons TP, Garraghty PE, Ommaya AK, Kaas JH, Taub E, Mishkin M (1991) Massive cortical reorganization after sensory deafferentation in adult macaques. Science 252:1857-1860.

Raymond LA, Blackstone CD, Huganir RL (1993) Phosphorylation of amino acid neurotransmitter receptors in synaptic plasticity. Trends Neurosci 16:147-153

Reubi JC, Cuénod M (1979) Glutamate release in vitro from corticostriatal terminals. Brain Res 176:185-188.

Ribak CE (1978) Aspinous and sparsely-spinous stellate neurons in the visual cortex of rats contain glutamic acid decarboxylase. J Neurocytol 7:461-478.

Sahyoun N, Vine HL III, Bronson O, Siegel-Greenstein F, Cuatrecasas P (1985) Cytoskeletal calmodulin-dependent protein kinase: characterization, solubilization, and purification from rat brain. J Biol Chem 260:1230-1237.

Sandell JH (1986) NADPH diaphorase histochemistry in the macaque striate cortex. J Comp Neurol 251:388-397.

Schiebler W, John R, Doucet J-P, Rothlein J, Greengard P (1986) Characterization of synapsin I binding to small synaptic vesicles. J Biol Chem 261:8383-8390.

Scholz WK, Palfrey HC (1991) Glutamate-stimulated protein phosphorylation in cultured hippocampal pyramidal neurons. J Neurosci 11:2422-2431

Scholz WK, Baitinger C, Schulman H, Kelly PT (1988) Developmental changes in $\mathrm{Ca}^{3+} /$ calmodulin-dependent protein kinase $\mathrm{II}$ in cultures of hippocampal pyramidal neurons and astrocytes. J Neurosci 8:1039_ 1051 .

Schulman H (1984) Phosphorylation of microtubule-associated proteins by a $\mathrm{Ca}^{2+} /$ calmodulin-dependent protein kinase. J Cell Biol 99: 11-19.

Schulman $\mathrm{H}$ (1988) The multifunctional $\mathrm{Ca}^{2+} /$ calmodulin-dependent protein kinase. In: Advances in second messenger and phosphoprotein research (Greengard P, Robinson GA, eds), pp 39-112. New York: Raven.

Shanks MF, Powell TPS (1981) An electron micrographic study of the termination of thalamocortical fibers in areas $3 \mathrm{~b}, 1$ and 2 of the somatic sensory cortex in the monkey. Brain Res 218:35-47.

Shenolikar S, Lickteig R, Hardie DG, Soderling TR, Hanley RM, Kelly $P$ (1986) Calmodulin-dependent multifunctional protein kinase. Eur J Biochem 161:739-744.

Siekevitz P (1991) Possible role for calmodulin and the $\mathrm{Ca}^{2+} / \mathrm{cal}-$ modulin-dependent protein kinase II in postsynaptic neurotransmission. Proc Natl Acad Sci USA 88:5374-5378

Sigel E, Baur R (1988) Activation of protein kinase C differently modulates neuronal $\mathrm{Na}^{+}, \mathrm{Ca}^{2+}$ and $\gamma$-aminobutyrate type A channels. Proc Natl Acad Sci USA 85:6192-6196.

Silva AJ, Stevens CF, Tonegawa S, Wang Y (1992a) Deficient hippocampal long term potentiation in $\alpha$-calcium-calmodulin kinase II mutant mice. Science 257:201-205.

Silva AJ, Paylor R, Wehner JM, Tonegawa S (1992b) Impaired spatial learning in $\alpha$-calcium-calmodulin kinase II mutant mice. Science 257 : 206-211.

Sloper JJ, Powcll TPS (1979) An experimental electron microscopic study of afferent connections to the primate motor and somatic sensory cortices. Philos Trans R Soc Lond [Biol] 285:199-226.

Sloper JJ, Hiorns RW, Powell TPS (1979) A qualitative and quantitative electron microscopic study of the neurons in the primate motor and somatic sensory cortices. Philos Trans R Soc Lond [Biol] 285: $141-171$.

Steward O (1983) Alterations in polyribosomes associated with den- 
dritic spines during the reinnervation of the dentate gyrus of the adult rat. J Neurosci 3:177-188.

Steward O, Levy WB (1982) Preferential localization of polyribosomes under the base of dendritic spines in granule cells of the dentate gyrus. J Neurosci 2:284-291.

Stone TW (1979) Amnino acids as neurotransmitters of corticofugal neurons in the rat: a comparison of glutamate and aspartate. $\mathrm{Br} \mathrm{J}$ Pharmacol 67:545-551.

Storm-Mathisen J (1977) Glutamic acid and excitatory nerve endings: reduction of glutamic acid uptake after axotomy. Brain Res 120:379386.

Streit $\mathbf{P}$ (1980) Selective retrograde labeling indicating the transmitter of neuronal pathways. J Comp Neurol 191:429-463.

Sugiura H, Yamauchi T (1992) Developmental changes in the levels of $\mathrm{Ca}^{2+} /$ calmodulin-dependent protein kinase $\mathrm{II} \alpha$ and $\beta$ proteins in soluble and particulate fractions of the rat brain. Brain Res 593:97104.

Sweetnam PM, Lloyd J, Gallombardo P, Malisan RT, Gallagher DW, Tallman JF, Nestler EJ (1988) Phosphorylation of the GABA benzodiazepine receptor alpha subunit by a receptor associated protein kinase. J Neurochem 51:1274-1284.

Takaishi T, Saito N, Tanaka C (1992) Evidence for distinct neuronal localization of gamma and delta subunits of $\mathrm{Ca}^{2+} /$ calmodulin-dependent protein kinase II in the rat brain. J Neurochem 58:1971-1974.

Thangnipon W, Storm-Mathisen J (1981) $\mathrm{K}^{+}$-evoked $\mathrm{Ca}^{2+}$-dependent release of $\mathrm{D}\left[{ }^{3} \mathrm{H}\right]$ aspartate from terminals of the cortico-pontine pathway. Neurosci Lett 23:181-186.

Tobimatsu $\Upsilon$, Fujisawa H (1989) Tissue-specific expression of four types of rat calmodulin-dependent protein kinase II mRNAs. J Biol Chem 364:17907-17912.

Tobimatsu T, Kameshita I, Fujisawa H (1988) Molecular cloning of the cDNA encoding the third polypeptide of brain calmodulin-dependent protein kinase II. J Biol Chem 263:16082-16086.

Vulliet PR, Woodgetl JR, Cohen P (1984) Phosphorylation of tyrosine hydroxylase by calmodulin-dependent multiprotein kinase. J Biol Chem 259:13680-13683.

Walaas SI, Lay Y, Gorelick FS, DeCamilli P, Moretti M, Greengard P (1988) Cell-specific localization of the $\alpha$-subunit of calcium-calmodulin-dependent protein kinase II in Purkinje cells in rodent cerebellum. Mol Brain Res 4:233-242.

Wall JT, Kaas JH, Sur M, Nelson RJ, Felleman DJ, Merzenich MM
(1986) Functional reorganization in somatosensory cortical areas 3b and 1 of adult monkeys after median nerve repair: possible relationships to sensory recovery in humans. J Neurosci 6:218-233.

Wallace C, Hawrylak N, Greenough WT (1991) A debate of current issues. In: Long-term potentiation (Baudry M, Davis JL, eds), pp 189-232. Cambridge, MA: MIT Press.

Winfield DA, Brooke RNL, Sloper JJ, Powell TPS (1981) A combined Golgi and electron microscopic study of the synapses made by the proximal axon and recurrent collaterals of a pyramidal cell in the somatic sensory cortex of the monkey. Neuroscience 6:1217-1230.

Wong-Riley MTT (1979) Changes in the visual system of monocularly sutured or enucleated cats demonstrable with cytochrome oxidase histochemistry. Brain Res 171:11-28.

Woodgett JR, Davison MT, Cohen P (1983) The calmodulin-dependent glycogen synthase kinase from rabbit skeletal muscle: purification, subunit structure and substrate specificity. Eur J Biochem 136: 481-487.

Woody CD, Alkon DL, Hay B (1984) Depolarization-induced effects of $\mathrm{Ca}^{2+}$ calmodulin-dependent protein kinase injection, in vivo, in single neurons of cal molor corlex. Brain Res 321:192-197.

Worley PF, Baraban JM, DeSouza EB, Snyder SH (1986) Mapping second messenger systems in the brain: differential localizations of adenylate cyclase and protein kinase C. Proc Natl Acad Sci USA 83 4053-4057.

Wu K, Huang Y, Adler J, Black IB (1992) On the identity of the major postsynaptic density protein. Proc Natl Acad Sci USA 89:3015-3019

Wuenschell C, Fisher RS, Kaufman DL, Tobin AJ (1986) In situ hybridization to localize mRNA encoding the neurotransmitter synthetic enzyme glutamic acid decarboxylase (GAD) in the mouse cerebellum. Proc Natl Acad Sci USA 83:6193-6197.

Yamauchi T, Fujisawa H (1983) Purification and characterization of the brain calmodulin-dependent protein kinase (kinase II), which is involved in the activation of tryptophan 5-monoxygenase. Eur J Biochem 132:15-21.

Yamauchi T, Sekihara S, Ohsako S (1991) Characterization of calci$\mathrm{um} /$ calmodulin dependent protein kinase II isoforms from forebrain and cerebellum. Brain Res 541:198-205.

Young AB, Bromberg MB, Penney JB Jr (1981) Decreased glutamate uptake in subcortical areas different by sensorimotor cortical ablation in the cat: J Neurosci 1:241-249. 